\title{
Performance Audit in Construction Organisations: Relevant Criteria and Analytical Procedures
}

\section{Bibigul Amanzholova}

Doctor of Science in Economics, Head of Department of Audit, Accounting and Finance

ORCID

E-mail: amanzholova@corp.nstu.ru

Novosibirsk State Technical University, Novosibirsk, Russia

\section{Viktoria Karakchieva}

Candidate of Sciences in Philology, Associate Professor

$\underline{\text { ORCID }}$

E-mail: karakchieva@corp.nstu.ru

Department of Foreign Languages, Novosibirsk State Technical University, Novosibirsk, Russia

Journal of Corporate Finance Research, Vol. 13, No. 2, pp. 81-103 (2019)

DOI: https://doi.org/10.17323/j.jcfr.2073-0438.13.2.2019.81-103

Received 8 January 2019 | Peer-reviewed 5 March 2019 | Accepted 3 June 2019 


\section{Performance Audit in Construction Organisations: Relevant Criteria and Analytical Procedures}

\section{Abstract}

Performance audit is becoming increasingly ubiquitous in commercial and business spheres internationally. Due to its important role in promoting efficient organisational and administrative practices, performance audit is becoming a subject more rigorously analised in the academic sphere.

This study seeks to develop and test analytical tools of performance audit in Russian construction organisations. We place emphasis on the industry-specific dimensions of information disclosure. We intend to offer a solution to several crucial challenges in the field, which will allow for the development of a comprehensive method to implement analytical procedures. This is done with a view towards obtaining and collating sufficient and adequate audit evidence to help achieve business goals.

In order to devise a consistent methodology, first, a link is highlighted between construction industry constraints and performance audit criteria. Second, an algorithm is developed to carry out comparative integrated estimation of performance audit criteria in order to shortlist relevant indicators. Third, the algorithm is tested using financial reporting of selected construction companies, which makes it possible to build a consistent system of performance audit criteria and identify a reliable set of controlled parameters.

A profile of practical analytical procedures, performance audit criteria and measurement indicators is formed through financial and performance audit and imbedded statistical methods. Implementing this approach will be seen to close some information gaps commonly found in the reporting data of construction industry, as it links the subject area of performance audit and the objective criteria of effectiveness, efficiency and economy.

The findings are presented with reference to existing statistical surveys on construction industry constraints. While recent studies provide a broader picture across construction industry, they do not address its regional aspects. As such, within this study we have carried out estimates of performance indicators for construction companies operating in the Novosibirsk region. The estimates are based on the information available through Professional Market and Company Analysis System. As a result, a system of performance audit criteria is identified in relation to the dimensions of effectiveness, efficiency and economy and a framework of controlled parameters is shaped. The level of disclosure concerning these parameters presented in a company's reporting is supposed to determine the decisions of stakeholders and potential investors.

In consideration of further research, this study highlights that it is necessary to identify and validate performance criteria in view of the fact that only few construction companies are profitable. The mix of qualitative and quantitative analytical procedures demonstrated herein is an effective approach to address the challenges of information integrity assessment. We consider that the most promising aspect of this study is the analysis of how the quality and amount of information disclosed in the reporting of construction companies affects their public image and business activities. This can be seen to have widespread industry and academic applications. Additionally, our approach represents a suitable framework for possible adaptation towards not only other industries, but also further development of the methodological approach itself.

Keywords: performance audit, effectiveness, efficiency, economy, construction organisations, statistical methods, analytical procedures, tax burden, cost of goods, material returns

JEL classification: G32, M42, P17 


\section{Introduction}

The role of auditing as an institutional mainstay and a business practice is evolving in line with economic, political and technological dynamics. Today, the idea of auditing is treated in a broad social context, at least in the context of social responsibility. Audit functions are no longer confined to only economic problems of a business. Rather, auditing is expected to ensure public confidence in the information presented in various types of reporting. A significant strand in the research literature emphasises that contemporary audit practices tend to go beyond the conventional framework of monitoring and analysis and focus on forecasting and developing recommendations.

We should take into consideration that current audit activities are carried against a business and socio-cultural backdrop which has been radically reshaped by technological development. In this technologically driven environment, traditional audit skills are no longer sufficient, and in this new context, the factors that influence audit effectiveness need consideration [1]. On the other hand, we can witness the growing availability of audit support systems [2] that may send erroneous signals that audit procedures are available to casual users. Researchers also point out that a pervasive feature of the current audit environment is multitasking, which they see as a cause of impaired performance in auditing [3]. In this context, it is particularly important to develop adequate methods of selecting from and interpreting massive amounts of information. These methods should be customised to concrete purposes in order to overcome the restrictions of standard audit support systems. Research literature provides examples of methods and analytical procedures developed to meet specific needs of audit entities [4]. Another prominent factor is technology integration in the auditing process. Since auditors tend to increasingly rely on restricting audit support systems, this adversely hinders the variety of thought in audit and leads to a stagnation in the evolution of better practices [2]. From this perspective, we consider any discussion around analytical procedures and methods in audit as a contribution towards resisting this negative tendency.

Performance audit is a system of controls that is carried out by regulators through analytical review activities to allow for reasonable conclusions as to whether the recipients of financial resources utilise them properly. Nevertheless, the question is still open as to which performance audit criteria should be selected as a reference against which the evidence is evaluated, classified and categorised.

Part of the problem lies in underdeveloped accounting information systems which restrict the implementation of performance audit procedures, as well as some industry-specific factors that influence criteria selection and evidence interpretation. The cases we have explored show that to provide a comprehensive assessment of company performance, researchers use both accounting (ROA, ROE) and market-based indicators, such as Tobins $Q$ $[5,6]$.
However, in the case of the Russian construction industry this approach is unacceptable because of the limited information available.

This seems to be inconsistent with growing information transparency and easier access to information, which are considered as prominent features of the current technologically driven environment. We should note that digitalisation only provides opportunities, and does not guarantee a sufficient level of information disclosure. Researchers have shown that corporate disclosure behaviour depends on many contextual and institutional factors such as economic development, legislation, sophisticated financial markets, as well as firm-level variables such as corporate governance and ownership structure [7].

As our observations show, Russian construction companies tend to publish only accounting, tax and statistical reporting. These kinds of reporting include mostly quantitative data, which restricts the capacity of performance auditing. The reported data from construction companies provides only a minimum of mandatory information to be disclosed in accordance with the legislation. Moreover, this reporting is formed retrospectively. This leads to the scarcity of information needed for balanced decision-making, as well as its low relevance from the perspective of current economic, social and technological requirements and standards.

For any national economy, a construction industry is vitally important, as it raises funds from both governments and private investors, and, most importantly, it greatly contributes to the social and economic development of the country. This serves to emphasise the importance of performance audit procedures in the Russian construction industry. However, there is a gap in theoretical and applied research on performance audit tools adjusted to accounting and reporting practices in construction organisations.

A baseline study of the construction industry enables us to reveal the most prominent constraints that hold back the performance of construction entities and subsequently shortlist the factors that shape the parameters of performance audit tools implementation.

Today, we have to state that the Russian construction industry is descending into deeper crisis. This conclusion is in line with the findings of RABC (The Rating Agency of Building Complex, Russia) that highlights the following crisis indicators: reduction of government contracts, significant decline of the amount of real estate developed, increasing arrears periods, and bankruptcy. According to analysts, the core of this recession is to be found in customers' insolvency as well as their financial uncertainty from a mid-term perspective. This has a direct impact on the developers' results and financial sustainability.

We should emphasise here that the customers' uncertainty comes not only from their insolvency, but also, to larger extent, their distrust of real estate developers and other fund-raisers. Therefore, neither the investment attractiveness of construction projects nor government efforts to 
promote mortgaging alone can combat the crisis. In this context, we appreciate the initiative of the Head of the Ministry of Construction to improve information transparency of developers and establish mandatory requirements to their information disclosures in terms of fairness and completeness. This puts the spotlight on performance audit, since, we strongly believe, this discipline is capable of providing a comprehensive solution to the problem of information quality with a view to providing an adequate evaluation of construction organisations' performance.

\section{Construction industry trends}

To gain a greater insight into Russian construction industry considerations, we now refer to official statistics [8]. For some time past, the industry has exhibited a marked slowdown. A slight growth of business in immediate post-crises period (2010-2014) was followed by a steady decrease (Figure 1).

Figure 1. Trends for the volume of work performed by the economic activity "Construction" in Russia (percentage) in terms of price comparison to the previous year (2006-2015)

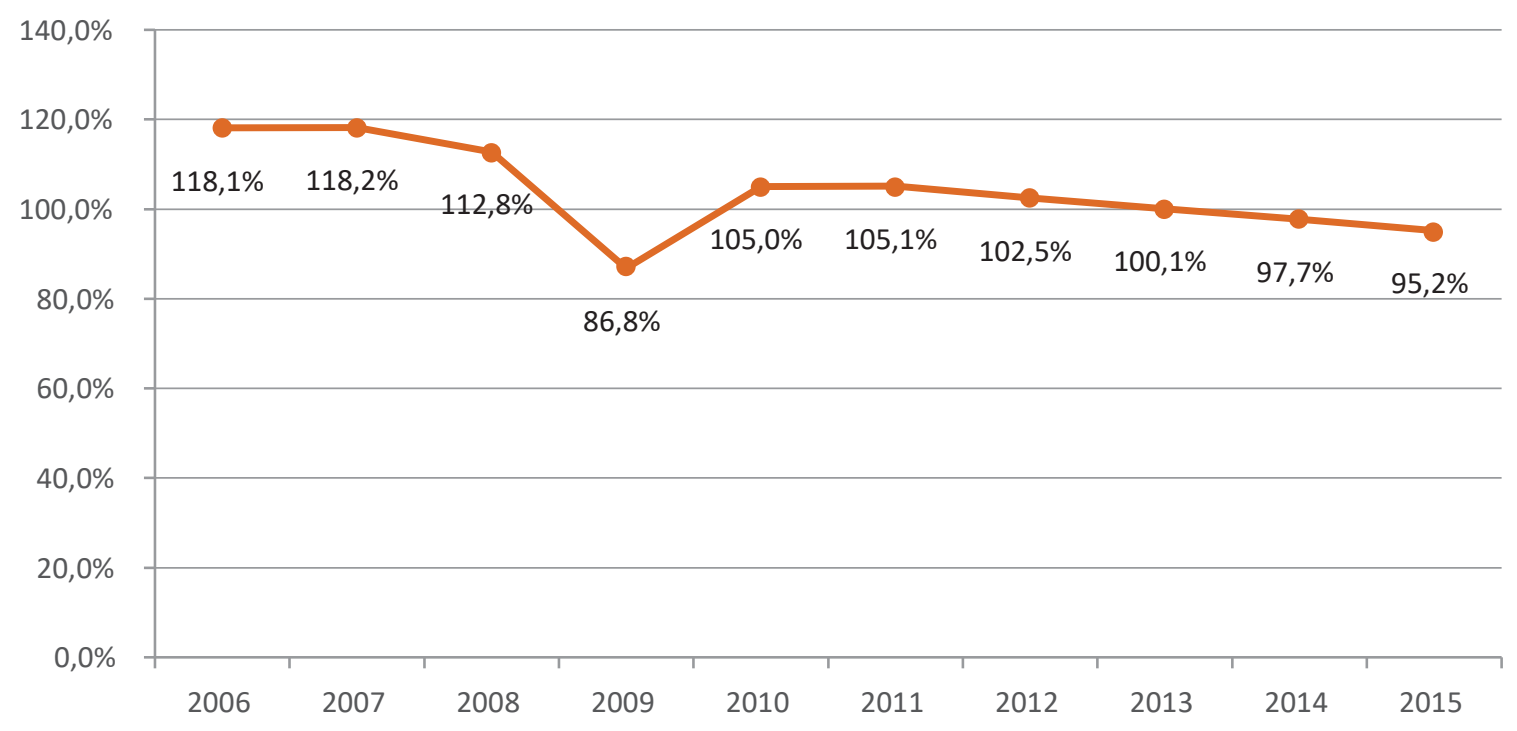

Figure 2. Construction industry constraints (response rate, \%) [9]

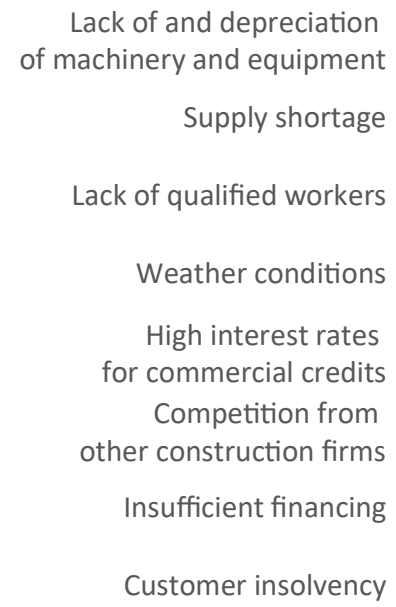

Lack of and depreciation of machinery and equipment

Supply shortage

Lack of qualified workers

Weather conditions

High interest rates for commercial credits

Competition from other construction firms

Insufficient financing

Customer insolvency

High prices for materials, structures and other outgoings

Lack of commericial orders

High levels of taxation

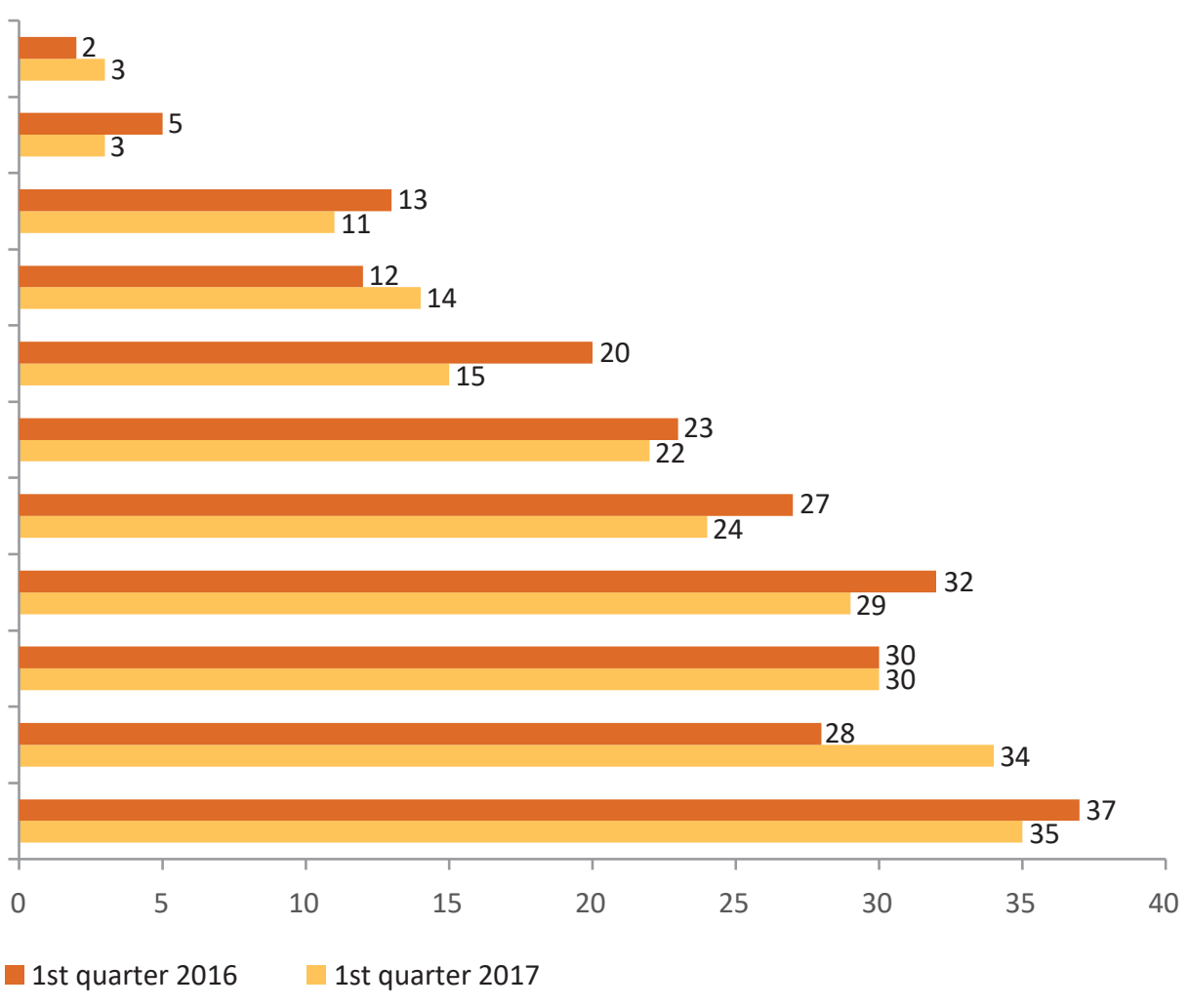


A number of constraints that hamper the development of the construction industry. The Russian Federal State Statistics Service (Rosstat) conducts sampling monitoring of construction organisations, collecting quarterly feedback and expert estimates from people involved in the construction business. This allows for identifying key negative factors to stiffen construction industry from the perspective of the professional community (Figure 2).

The feedback from the respondents is in line with the data illustrating construction industry trends (Figure 3). Most prominent are such trends as the progressive growth of overdue accounts receivable, lengthy default periods, and the practically uninterrupted growth of fully depreciated manufacturing facilities. Other indicators in the 'red zone' concern the growing amount of bank loans in arrears. For example, at the end of 2013 overdue bank loans in construction industry totaled 7182 million roubles, in 2014 this increased six-fold and reached 49936 million roubles. Statistics reveal that in 2015 the amount of overdue bank loans was as much as 54434 million roubles.

\section{The effect of industry development factors on individual enterprise performance}

The pattern of factors listed above shaped the idea of implementing performance audit tools in the construction industry. The case is that the impact of these factors on the performance of construction companies seems evident as long as it is considered per se. However, if we have a closer look at the performance criteria, the nature of their impact becomes far more ambiguous. Consider the factor 'Lack and depreciation of machines and equipment'. We cannot clearly categorise it as a negative factor influencing either effectiveness or economy.

Among the most relevant construction industry constraints, we can count the following:

- $\quad$ high level of taxation;

- high prices for materials, structures and articles;

- high interest for commercial credit;

- lack and depreciation of machines and equipment.

To provide a rationale for performance audit criteria patterns to be utilised in the construction industry, we have investigated how these criteria influence enterprise performance. The first significant factor is tax burden that shows the amount of resources a company has to divert to its taxation duties.

As we have mentioned above, construction business professionals see a high taxation rate as the most significant constraint. This means that the behaviour of high taxation factor needs further thorough consideration. Different ratios are used as indicators measuring tax burden, such as tax payable totals in relation to revenue, other earnings, and profit. Figure 4 shows the historical tax burden calculated by the method adopted by Federal Tax Statistics Service of Russia.

Figure 3. Trends for business indicators of Russian construction organisations (2007-2015) - authors' calculations

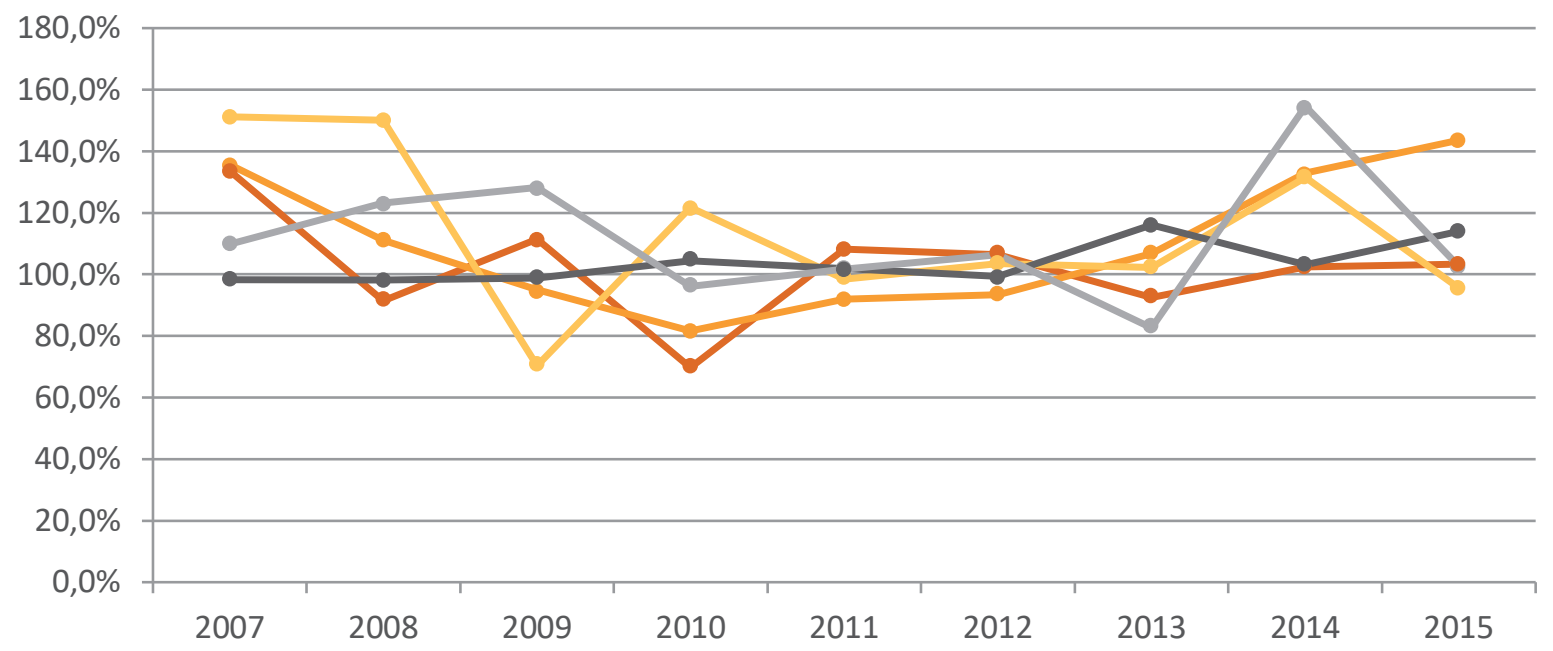

- Tax payments in relation to revenue in construction organisations, $\%$

- Overdue accounts receivable, millions of roubles

- Fixed capital investment in construction, billion roubles (measured in contemporary prices)

- Percentage of fully depreciated manufacturing facilities (measured at the year-end)

Average days with payments outstanding 
Figure 4. Tax burden in Russian construction industry, 2015-2016, percentage [10]

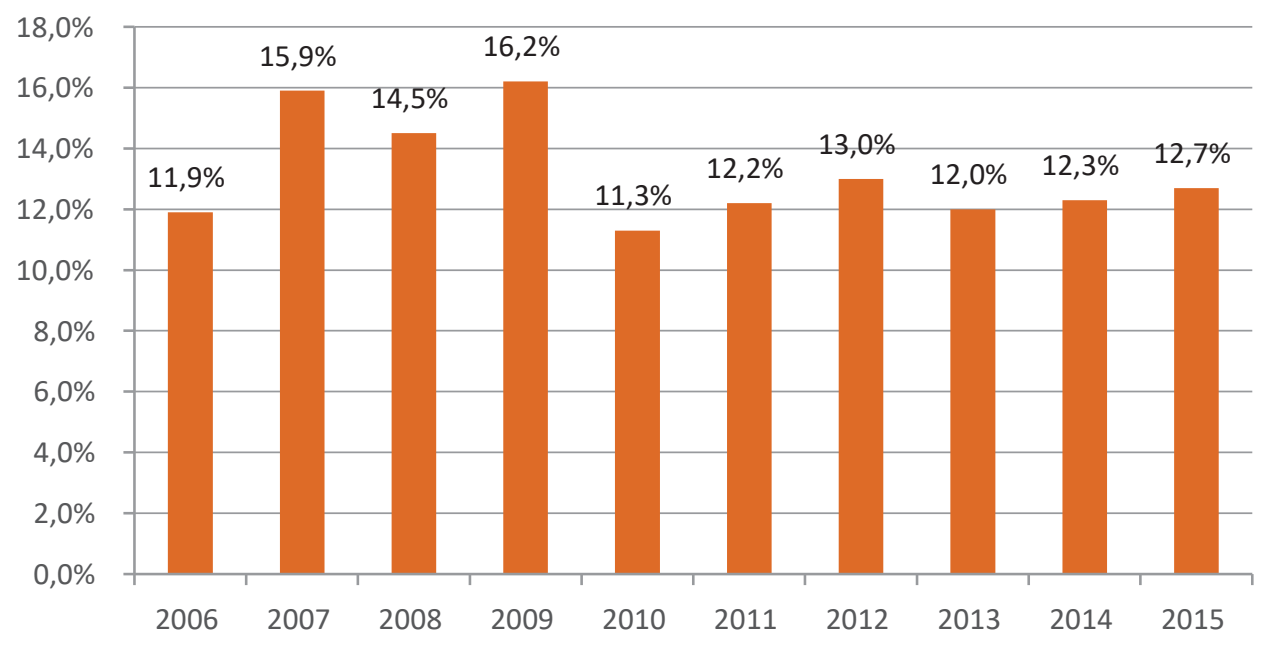

Tax burden as a percentage of revenue

Figure 5. Construction works cost pattern in the Russian Federation, for 2015 (valued at actual costs) [11]

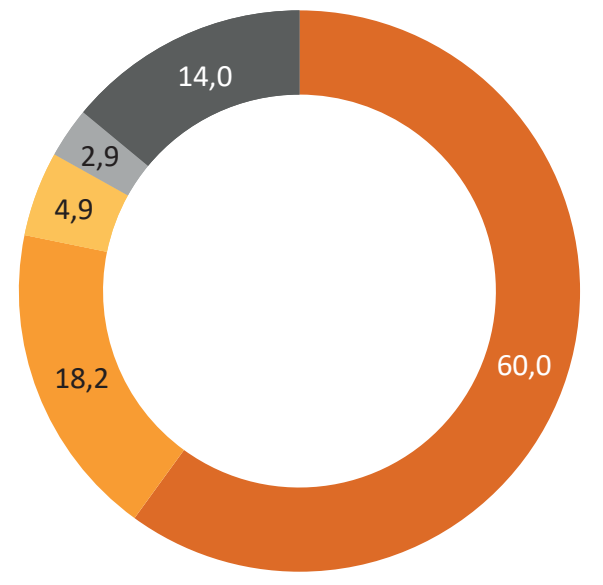
- Material costs
- Labour costs
- Deductions from pension, social and medical insurance
- Fixed assets depreciation
- Miscellaneous expenditures

Thus, the pattern of controlled parameters enabling us to identify performance audit criteria should include profit, sales revenue, other earnings, and tax payable total.

Another constraint is high prices for materials, structures and articles. The power of this factor stems from the fact that construction industry is labour and material intensive. Figure 5 shows construction works cost pattern. Material costs account for more than $50 \%$ of estimated construction budget. This emphasises the importance of thorough monitoring of the procurement and depreciation of construction materials that should take into account their specific characteristics and feasibility.

To measure the impact of material costs on the performance of construction organisations, we suggest using the ratios of material returns and costing to sales revenue as the elements of performance audit criteria.

Construction investment is decreasing. The first quarter of 2014 saw a slowdown of business activities within the industry. The demand for construction contracts shrank and the financial standing of developers deteriorated, not least due to the inflation. One obstacle to investment activity in the industry is high interest for commercial credits. Its significance is proven by the increasing amount of unsettled bank loans and other borrowings of companies in construction industry. The two indicators to measure this factor's impact are borrowed funds turnover and returns on debt. Every year Rosstat summarises the condition of the country's construction machinery fleet, where it repeatedly states that construction organisations face a reduction of their current machinery fleet and a growth of machinery with an expired service life [12]. It is important to note that the proportion of foreign manufactured machinery is substantial.

To measure the impact of 'Lack and depreciation of machines and equipment' on company performance, it makes sense to use such indicators as fixed assets turnover and returns on fixed assets.

To provide an overall assessment of business processes in the construction industry in terms of economy, we introduce elasticity coefficients where the numerator shows the changing value of costs (resources), and the denominator indicates the change in revenue within comparison periods. Given the economy criteria are met, the growth rate of the nominator will be smaller than that of the denominator. Economy is measured in terms of savings or overruns of resources utilised against actual outcome. Audit practices measure economy using 'performance to plan' indicators that consider changes in different resources (factors) against outcomes. So overrun/saving measuring methods involve the information provided by plans, budgets and estimates. We think that this information can be expanded to include effectiveness and efficiency 
assessment as well. Our approach is aimed at establishing the comparability of performance assessment for different construction companies over time. That is why our approach involves the relations of changing factors and revenue.

To measure the performance of construction companies and lay the grounds for their development, we need a comprehensive approach that would enable us to evaluate the contribution of the key factors under consideration. A comprehensive solution is provided by performance audit procedures, as they provide relevant accounting and analytical information that enables users (including the public) to determine how well a company is performing by comparing its results to priority objectives in compliance with the costs and quality of resources consumed. However, prior investigations into fundamental and practical issues of auditing performance confined it only to the public sector of the economy. In today's resource-constraint environment, it is necessary to broaden its applicability and expand it to account for the private sector, including private enterprises in construction industry.

As we mentioned above, an advantage of performance auditing is a comprehensive evaluation in terms of effectiveness, efficiency and economy. The glossary of basic terms compiled by Accounts Chamber of the Russian Federation defines these terms as follows:
1) The efficiency of public spending is a relation between the outcomes (product, services and other) produced by public funds recipient and the input of material, financial, and labour resources used to deliver those outcomes.

2) The effectiveness of public spending - the extent to which actual outcomes delivered by a public funds recipient match the planned objectives.

3) The economy of public spending attains the recipient's planned objectives at minimum costs or achieving best results within the planned budget [13].

For performance criteria, auditors may take numerous quality and quantity metrics that characterise the subject matter of audit in terms of its organisation, processes, results and/or business activities to provide evidence that enables to assess how reasonably public funds are utilised. In the practice of performance audit, criteria patterns may vary in compliance with the audit subject matter and the nature of business under consideration. The main requirement is that the criteria pattern be sufficient for making reasonable conclusions, in line with the objectives of auditing procedures utilised [14].

Therefore, it is possible to make a connection between performance audit criteria and the industry-specific constraints in the construction industry as described above (Table 1).

Table 1. Linkage between performance audit criteria and construction industry constraints

\begin{tabular}{|c|c|c|c|}
\hline \multirow{2}{*}{ Constraints } & \multicolumn{3}{|c|}{ Performance audit criteria } \\
\hline & efficiency & effectiveness & economy \\
\hline High level of taxation & $\begin{array}{l}\text { Tax burden in relation to } \\
\text { revenue }\end{array}$ & $\begin{array}{l}\text { Tax burden in relation to } \\
\text { profit }\end{array}$ & $\begin{array}{l}\text { Tax elasticity in relation to } \\
\text { revenue }\end{array}$ \\
\hline $\begin{array}{l}\text { High prices for materials, } \\
\text { structures, articles }\end{array}$ & Cost to sales revenue & Material returns & $\begin{array}{l}\text { Elasticity of price of goods } \\
\text { in relation to revenue }\end{array}$ \\
\hline $\begin{array}{l}\text { High interest for commercial } \\
\text { credits }\end{array}$ & Borrowed funds turnover & Returns on debts & $\begin{array}{l}\text { Elasticity of borrowed cap- } \\
\text { ital in relation to revenue }\end{array}$ \\
\hline $\begin{array}{l}\text { Lack and depreciation of ma- } \\
\text { chines and equipment }\end{array}$ & $\begin{array}{l}\text { Fixed assets turnover; } \\
\text { Capital / output ratio }\end{array}$ & Returns on fixed assets & $\begin{array}{l}\text { Elasticity of equity in rela- } \\
\text { tion to revenue }\end{array}$ \\
\hline
\end{tabular}

This system is directed towards the overall goal of improving the relevant performance indicators selected as audit criteria. It will allow for comprehensive control over performance factors, and thus foster excellence of management and workforce performance in construction organisations. To fulfil this task, we suggest a comprehensive analysis using the integral estimation method.

\section{Applying integral estimation method to audit criteria}

The integral estimation method is based on an approach to integrated indicators that is commonly used with complex and multidimensional social and economic phenomena. The baseline indicators are first converted and then convolved to form an aggregate multivariable estimate.
A similar approach involves using integrated indicators developed by a number of international organisations, for example, the Human Development Index suggested in UN Development Program [15]. Generally, the algorithms of obtaining integrated indices are very similar in all methods and follow the same sequence:

- $\quad$ selection of baseline indices $\left(\mathrm{x}_{\mathrm{i}}\right)$ - primary data describing the phenomenon under study;

- primary data normalising - reducing to one value by the method of average, relative difference and other methods;

- integration of normalised data $\left(\mathrm{x}_{\mathrm{n}}\right)$ by convolving interim metrics calculated through either multiplicative or additive methods. 
Figure 6. Algorithm of comparative integrated evaluation of performance audit criteria

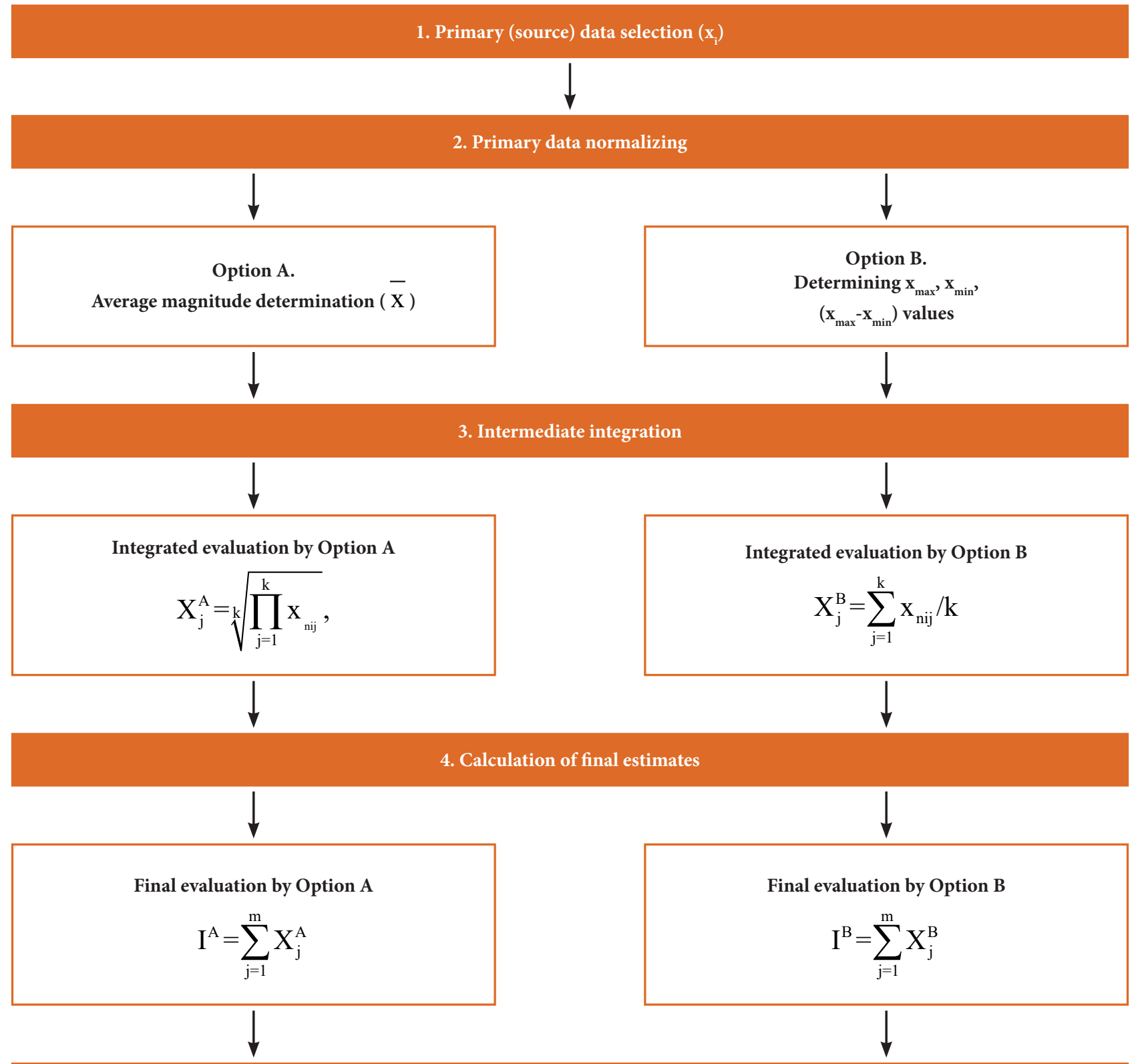

5. Ranking the final estimates for reporting periods

$\downarrow$

6. Selecting relevant indicators of efficiency, effectiveness and economy

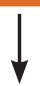


These steps may involve a wide range of normalising and integration procedures. We used the most appropriate procedures individually, as well as a mix of several procedures.

For example, for primary data normalising the following procedures were used:

1. Normalising by the method of average. A working method of data unification $\left(\mathrm{x}_{\mathrm{n}}\right)$ is the comparison of individual values of every index $\left(\mathrm{x}_{\mathrm{i}}\right)$ against the actual total average.

$\mathrm{x}_{\mathrm{n}}=\frac{\mathrm{x}_{\mathrm{i}}}{\mathrm{x}}$.

The exceedance of an index being assessed as a negative trend, normalising is calculated in reverse:

$\mathrm{x}_{\mathrm{n}}=\frac{\overline{\mathrm{x}}}{\mathrm{x}_{\mathrm{i}}}$.

2. Normalising by range of actual values deviation. Baseline data $\left(\mathrm{x}_{\mathrm{i}}\right)$ are unified by comparison against the minimum $\left(\mathrm{x}_{\min }\right)$ and maximum $\left(\mathrm{x}_{\max }\right)$ values of the indicator.

$\mathrm{X}_{\mathrm{n}}=\frac{\mathrm{X}_{\mathrm{i}}-\mathrm{X}_{\min }}{\mathrm{x}_{\max }-\mathrm{X}_{\min }}$.

This integrated assessment procedure is known as the method of relevance difference [10]. For the indices describing negative trends, the normalising formula will be constructed as follows:

$\mathrm{x}_{\mathrm{n}}=1-\frac{\mathrm{x}_{\mathrm{i}}-\mathrm{x}_{\text {min }}}{\mathrm{x}_{\text {max }}-\mathrm{x}_{\text {min }}}$.

The existing methods may differ in their ways of data harmonising to a single integrated magnitude, i.e. obtaining finite or intermediate values of an integrated indicator. For this purpose, power mean formulae are widely used. Some methods encapsulate the stage of weight indicators rating with follow-up procedures such as assessment of various experts' opinions. These methods utilise the weighted arithmetical mean that will average out the values of standardised indicators.

To form a list of integral indicators for construction industry constraints, we can use two options: (A) and (B) to investigate their comparability.

Option A involves normalising indicators' values by comparing them against the average magnitude, with the geometrical mean being used in intermediate integrating procedures:

$\mathrm{X}_{\mathrm{j}}=\sqrt[k]{\prod_{\mathrm{i}=1}^{\mathrm{k}} \mathrm{X}_{\mathrm{ni}}}$,

where $\mathrm{X}_{\mathrm{j}}$ is the intermediate integrated indicator for a separate set of conditions $\mathrm{j}$;

$\mathrm{k}$ is the number of indicators describing the set of conditions $\mathrm{j}$.

Option B involves normalising individual indicators by the relative difference method. Intermediate integrating is completed with the arithmetical mean.
The option selected for indicators normalisation will also influence further procedures of data integrating. In case that the normalised values are presented as relative deviations from the mean or minimum value and then further averaged (Options $\mathrm{A}$ and $\mathrm{B}$ ), the finite aggregate can be calculated as an average magnitude.

It is then feasible to rank the consolidated aggregates on an annual basis, and select the most significant effectiveness and efficiency indicators. This is achieved by choosing the best year for each organisation and comparing effectiveness and efficiency indicators obtained by both methods.

The step-by-step sequence of the comparative integrated assessment method is summarised in the flow-chart (Figure 6).

Thus, the comparative assessment method of performance audit criteria allows for a serious improvement of the auditor's analytical tools. Firstly, it suggests reasonable selection procedures for efficiency, effectiveness and economic indicators, which provides representative evidence for the auditor's findings. Secondly, the method can be used to rate the industry players and so it provides the basis on which to compare performance criteria of the auditee against those of its competitors. Thirdly, relevant indicators allow for the building up of a consolidated framework of controlled parameters whose behaviour can be described by means of factor analysis to work out relevant recommendations.

\section{Using the comparative integral assessment method to review the performance criteria of construction organisations in Novosibirsk region}

To identify the relevant performance criteria which provide a fair view of construction organisations' performance in terms of their effectiveness, efficiency and economy, we used available information on financial and operational activities of sixteen construction organisations operating in the Novosibirsk region. To calculate performance indicators, we used accounting (financial) reporting from the same sample. The estimates were calculated with reference to the information provided by Professional Market and Company Analysis System (SPARK).

The examined data showed that ten companies under consideration were in the red zone (suffering net losses) throughout several years, so only six organisations could be shortlisted. Their profit trends are illustrated below (Figure 7).

As the graph shows, the companies numbered as 1 and 14 earned the highest net profit, the best year for both of them being 2013.

Consider the revenue trends shown in Figure 8. 
Figure 7. Net profit trends for six construction organisations operating in Novosibirsk Region selected from the sample of 2010-2014

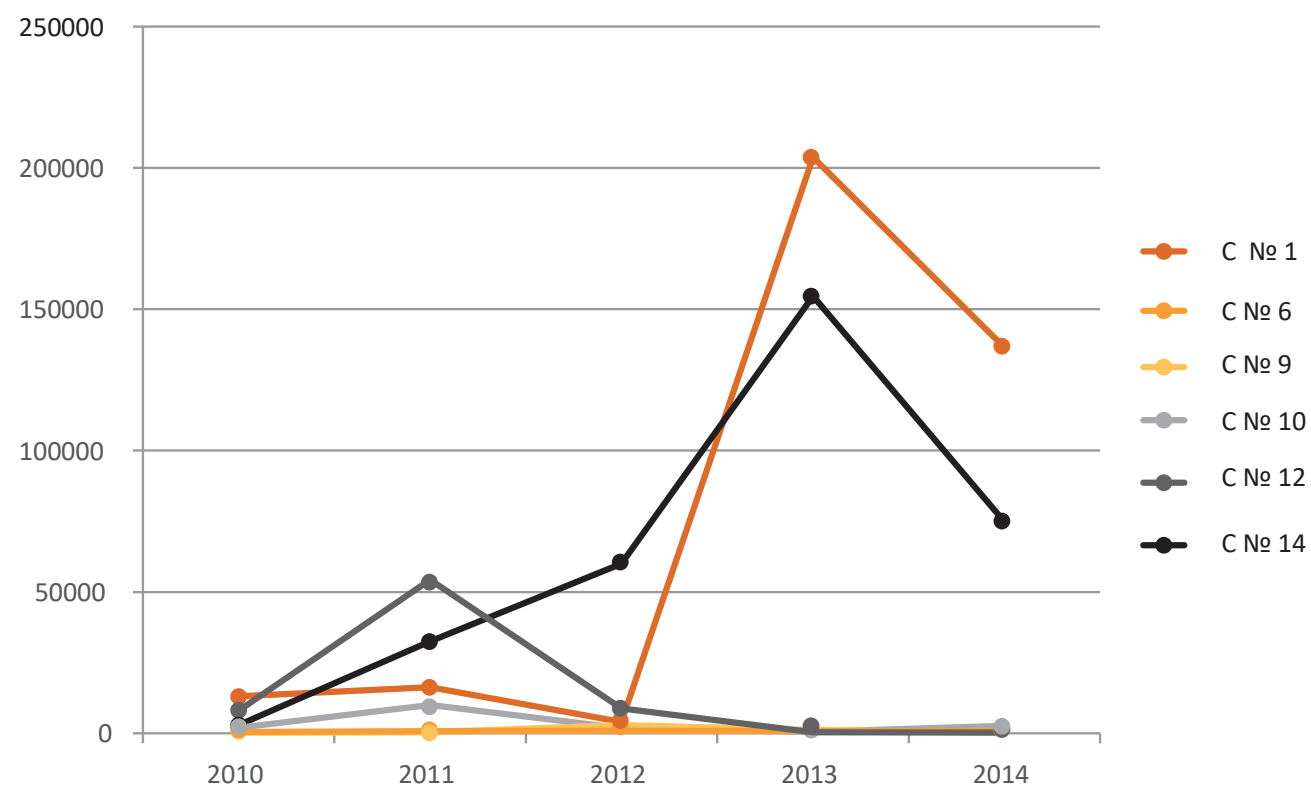

Figure 8. Revenue trends for six construction organisations operating in Novosibirsk Region selected from the sample of 2010-2014

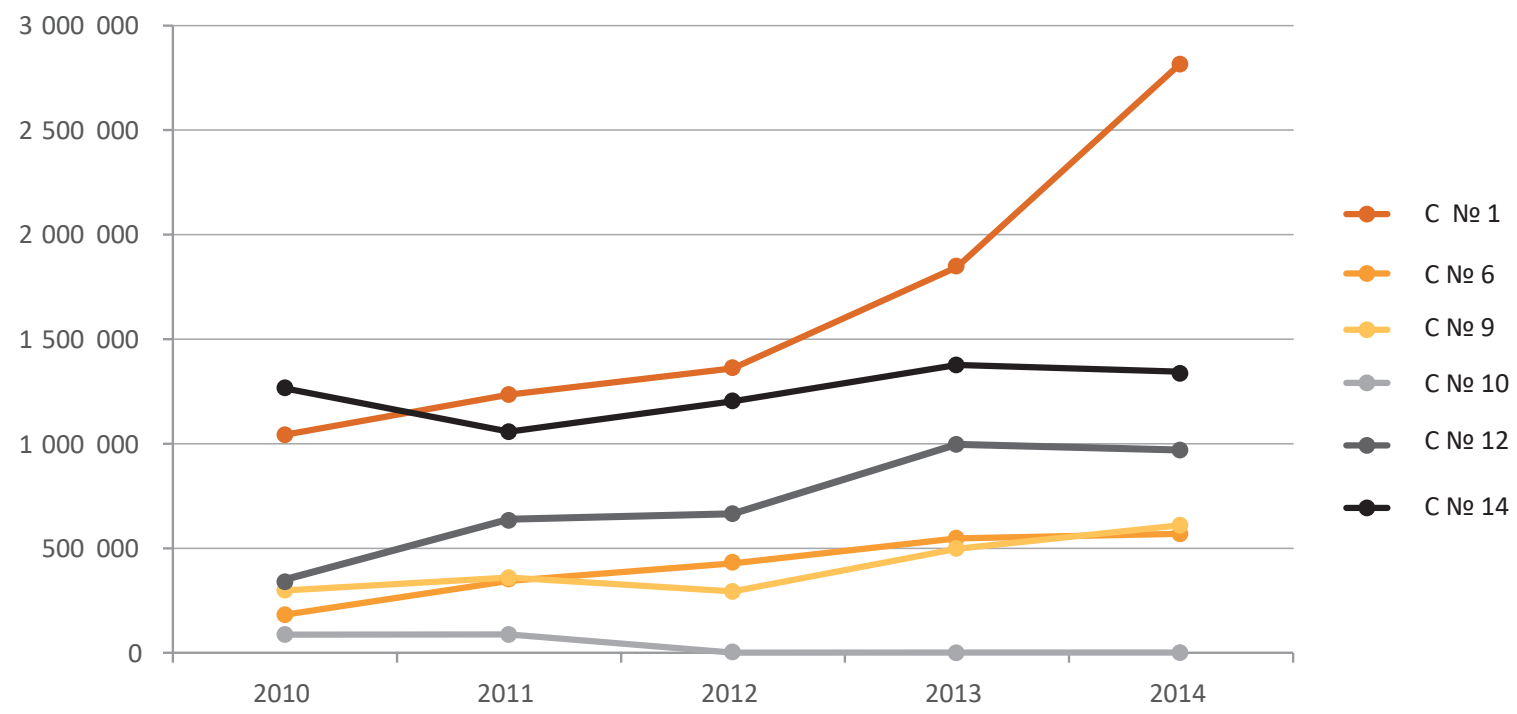

The revenue figures show the same trend. Company 1 and Company 14 have the highest rates. To continue with the analytical procedures, we have chosen Company 14 since it is the only company in our sample that has its accounting reports regularly published, which should ensure the quality of its reporting. Analysis of the data from construction companies in the Novosibirsk region confirms the findings of Russian researchers. In this vein, E. Senatorova [16] points out that the Russian construction industry tends to provide only mandatory accounting and tax reporting. As for non-financial reporting, construction ranks highest among the industries that are unlikely to disclose that kind of information. Herewith we will examine the sequence summarised in Figure 6.
To complete basic data sets, performance audit criteria should be calculated (the results are summarised in Table 2). Consider some of the following factors. For "High level of taxation", the following indicators are assigned: tax burden to sales revenue, current corporate income tax, tax to profit ratio. For "High prices for materials, structures and articles", the relevant indicators are cost to sales revenue, price of goods, and material returns. For "High interest for commercial credits" - borrowed funds turnover, average annual cost of debt, and returns on debt. For "Lack and depreciation of machines and equipment", the appropriate indicators are fixed asset turnover ratio, average annual value of fixed assets and returns on fixed assets. 
Table 2. Calculation of performance audit criteria for a sample Joint Venture (2011-2015)

\begin{tabular}{|c|c|c|c|c|c|c|}
\hline $\begin{array}{l}\text { Con- } \\
\text { straints }\end{array}$ & Indicators & 2011 & 2012 & 2013 & 2014 & 2015 \\
\hline 1 & 2 & 3 & 4 & 5 & 6 & 7 \\
\hline \multirow{9}{*}{ 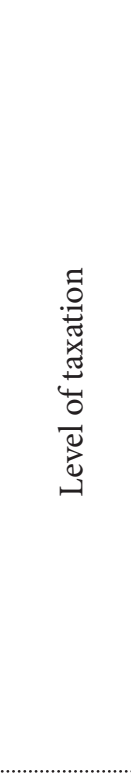 } & \multicolumn{6}{|c|}{ Efficiency } \\
\hline & Tax payment (TP), thousands of roubles. & 3029 & 15671 & 25722 & 33913 & 29281 \\
\hline & Revenue (R), thousand roubles & 1265615 & 1057643 & 1203466 & 1376886 & 1345318 \\
\hline & $\begin{array}{l}\text { Tax burden to Revenue }\left(\mathrm{TB}_{\mathrm{R}}\right) \text {, } \\
\qquad \mathrm{TP} / \mathrm{R}\end{array}$ & 0.24 & 1.481 & 2.14 & 2.46 & 2.18 \\
\hline & \multicolumn{6}{|c|}{ Effectiveness } \\
\hline & Net profit $(P)$ & 2908 & 32562 & 59942 & 154647 & 74897 \\
\hline & $\begin{array}{c}\text { Tax burden to Profit }\left(\mathrm{TB}_{\mathrm{P}}\right) \\
\mathrm{TP} / \mathrm{P}\end{array}$ & 104.16 & 48.13 & 42.91 & 21.93 & 39.09 \\
\hline & \multicolumn{6}{|c|}{ Economy } \\
\hline & $\begin{array}{l}\text { Elasticity coefficient of taxes to revenue } \\
\qquad\left(\mathrm{E}_{\mathrm{TP} / \mathrm{P}}\right) \\
\left(\mathrm{TP}_{1}-\mathrm{TP}_{0}\right) /\left(\mathrm{R}_{1}-\mathrm{R}_{0}\right)\end{array}$ & 0.957 & -0.061 & 0.069 & 0.047 & 0.147 \\
\hline \multirow{9}{*}{ 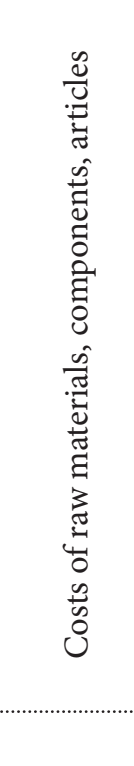 } & \multicolumn{6}{|c|}{ Efficiency } \\
\hline & Cost of goods (CG), thousands of roubles & 1066089 & 742053 & 775189 & 936102 & 909110 \\
\hline & $\begin{array}{l}\text { Cost of revenue } \\
\mathrm{C} / \mathrm{R}\end{array}$ & 0.84 & 0.70 & 0.64 & 0.68 & 0.67 \\
\hline & \multicolumn{6}{|c|}{ Effectiveness } \\
\hline & Material costs (MC), thousands of roubles & 586349 & 408129 & 426354 & 514856 & 500011 \\
\hline & $\begin{array}{l}\text { Material returns (MR) } \\
\mathrm{MC} / \mathrm{R}\end{array}$ & 2.15 & 2.59 & 2.82 & 2.67 & 2.69 \\
\hline & \multicolumn{6}{|c|}{ Economy } \\
\hline & $\begin{array}{l}\text { Elasticity coefficient of the cost of goods to } \\
\text { revenue }\left(\mathrm{E}_{\mathrm{CG} / \mathrm{R}}\right) \\
\left(\mathrm{CG}_{1}-\mathrm{CG}_{0}\right) /\left(\mathrm{R}_{1}-\mathrm{R}_{0}\right)\end{array}$ & -5.68 & 1.56 & 0.23 & 0.93 & 0.86 \\
\hline & \multicolumn{6}{|c|}{ Efficiency } \\
\hline \multirow{6}{*}{ 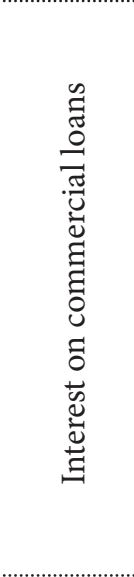 } & $\begin{array}{l}\text { Average annual amount of debt (DC), } \\
\text { thousands of roubles }\end{array}$ & 748909 & 734374 & 650277 & 589952 & 627999 \\
\hline & $\begin{array}{c}\text { Debt turnover }\left(\mathrm{T}_{\mathrm{D}}\right) \\
\mathrm{R} / \mathrm{DC}\end{array}$ & 1.69 & 1.44 & 1.85 & 2.33 & 2.14 \\
\hline & \multicolumn{6}{|c|}{ Effectiveness } \\
\hline & $\begin{array}{l}\text { Returns on debt }\left(\mathbf{R}_{\mathrm{D}}\right) \\
\mathrm{P} / \mathrm{DC}\end{array}$ & 0.00 & 0.04 & 0.09 & 0.26 & 0.12 \\
\hline & \multicolumn{6}{|c|}{ Economy } \\
\hline & $\begin{array}{l}\text { Elasticity coefficient of debt capital to reve- } \\
\text { nue }\left(\mathrm{E}_{\mathrm{D} / \mathrm{R}}\right) \\
\left(\mathrm{DC}_{1}-\mathrm{DC}_{0}\right) /\left(\mathrm{R}_{1}-\mathrm{R}_{0}\right)\end{array}$ & -0.76 & 0.24 & -0.81 & -0.02 & -2.50 \\
\hline
\end{tabular}




\begin{tabular}{|c|c|c|c|c|c|c|}
\hline \multirow{8}{*}{ 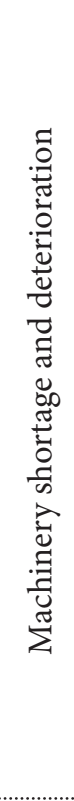 } & \multicolumn{6}{|c|}{ Efficiency } \\
\hline & $\begin{array}{c}\text { Average annual value of fixed assets }(\mathrm{FA}) \\
\text { thousands of roubles }\end{array}$ & 720372 & 671384 & 668643 & 708279 & 721756 \\
\hline & $\begin{array}{l}\text { Fixed assets turnover }\left(\mathrm{T}_{\mathrm{FA}}\right) \\
\mathrm{R} / \mathrm{FA}\end{array}$ & 1.76 & 1.58 & 1.79 & 1.94 & 1.86 \\
\hline & $\begin{array}{c}\text { Capital intensity ratio }(\mathrm{CI}) \\
\mathrm{FA} / \mathrm{R}\end{array}$ & 0.57 & 0.63 & 0.56 & 0.51 & 0.54 \\
\hline & \multicolumn{6}{|c|}{ Effectiveness } \\
\hline & $\begin{array}{c}\text { Returns on fixed assets }\left(\mathbf{R}_{\mathrm{FA}}\right) \\
\text { P/FA }\end{array}$ & 0.42 & 5.05 & 8.65 & 21.37 & 10.40 \\
\hline & \multicolumn{6}{|c|}{ Economy } \\
\hline & $\begin{array}{l}\text { Elasticity coefficient of fixed assets to reve- } \\
\text { nue (EFA/R) } \\
\qquad\left(\mathrm{FA}_{1}-\mathrm{FA} \mathrm{F}_{0}\right) /\left(\mathrm{R}_{1}-\mathrm{R}_{0}\right)\end{array}$ & 1.57 & 0.26 & 0.33 & 0.18 & 0.12 \\
\hline
\end{tabular}

Following the algorithm, the next step is to calculate the average value, normalise baseline data, and make an intermediate integral assessment by the two methods (Options A and B) for the six sample organisations. The findings for one of the organisations under consideration (below referred to as a Joint Venture) calculated by Option A are presented in Table 3 and 4. Table 3 summarises the factors of "High tax rate" and "High price for materials, structures and articles", and Table 4 summaris- es those of "High interest for commercial credits" and "Lack and depreciation of machines and equipment". The evidence herein brings us to the conclusion that reference periods for the high taxation factor is the year of 2011, for "High price for materials, structures and articles" - 2013, and for "High interest for commercial credits" and "Lack and depreciation of machines and equipment" the reference periods are 2013 and 2014 respectively.

Table 3. Intermediate integrated estimates for High tax rate and High price of materials, components, and equipment for the reporting period of 2011-2015, Option A

\section{High level of taxation}

\begin{tabular}{|c|c|c|c|c|c|c|c|c|}
\hline$\underset{\varpi}{\tilde{\sigma}}$ & 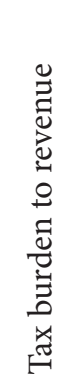 & 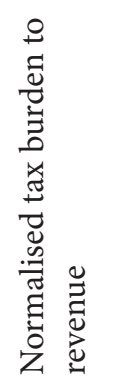 & 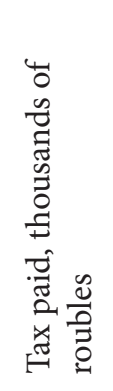 & 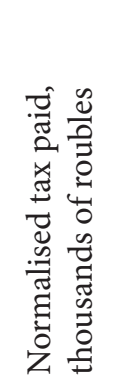 & 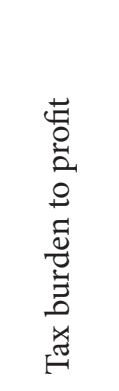 & 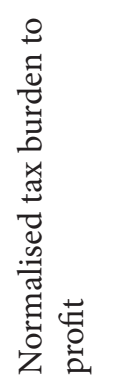 & 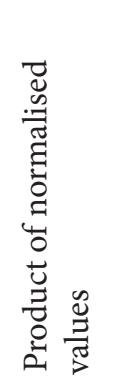 & 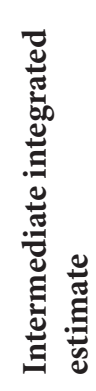 \\
\hline 2011 & 0.24 & 7.101 & 3029 & 7.105 & 104.16 & 0.491 & 24.825 & 2.917 \\
\hline 2012 & 1.48 & 1.147 & 15671 & 1.3731 & 48.13 & 1.064 & 1.677 & 1.188 \\
\hline 2013 & 2.13 & 0.795 & 25722 & 0.836 & 42.91 & 1.194 & 0.794 & 0.926 \\
\hline 2014 & 2.46 & 0.690 & 33913 & 0.634 & 21.92 & 2.336 & 1.023 & 1.007 \\
\hline 2015 & 2.18 & 0.780 & 29281 & 0.735 & 39.09 & 1.310 & 0.752 & 0.909 \\
\hline $\bar{x}$ & 1.69 & $\mathrm{x}$ & 21523 & $\mathrm{x}$ & 51.24 & $\mathrm{x}$ & $\mathrm{x}$ & $\mathrm{x}$ \\
\hline
\end{tabular}




\section{High price of materials, structures, articles}

\begin{tabular}{|c|c|c|c|c|c|c|c|c|}
\hline 䒕 & 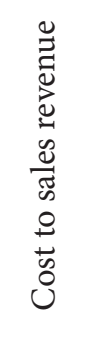 & 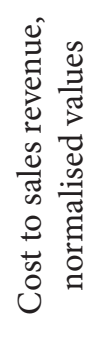 & 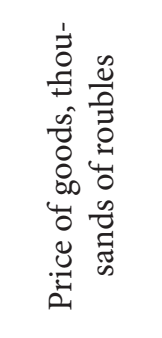 & 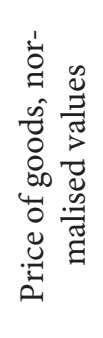 & 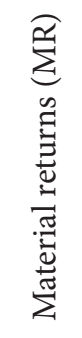 & 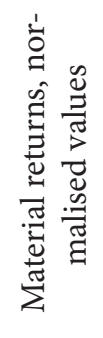 & 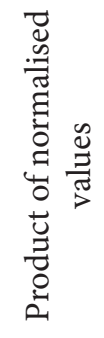 & 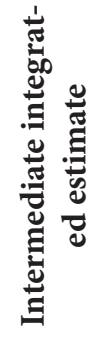 \\
\hline 2011 & 0.84 & 0.841 & 1066089 & 0.830 & 2.16 & 0.834 & 0.583 & 0.835 \\
\hline 2012 & 0.70 & 1.010 & 742053 & 1.193 & 2.59 & 1.001 & 1.207 & 1.064 \\
\hline 2013 & 0.64 & 1.100 & 775189 & 1.142 & 2.82 & 1.090 & 1.371 & 1.111 \\
\hline 2014 & 0.68 & 1.042 & 936102 & 0.946 & 2.67 & 1.033 & 1.019 & 1.006 \\
\hline 2015 & 0.67 & 1.048 & 909110 & 0.974 & 2.69 & 1.039 & 1.062 & 1.020 \\
\hline$\overline{\mathrm{x}}$ & 0.71 & $\mathrm{x}$ & 885708 & $\mathrm{x}$ & 2.59 & $\mathrm{x}$ & $\mathrm{x}$ & $\mathrm{x}$ \\
\hline
\end{tabular}

Table 4. Intermediate integrated estimates for high interest on commercial loan and machinery shortage and deterioration for the reporting period of 2011-2015, Option A

\section{High interest on commercial loan}

\begin{tabular}{|c|c|c|c|c|c|c|c|c|}
\hline 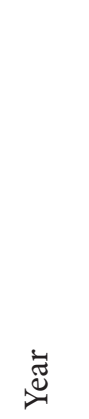 & 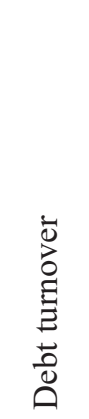 & 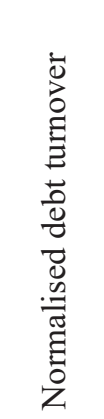 & 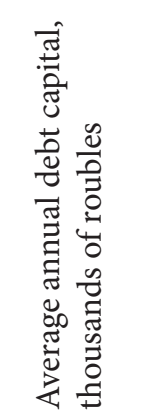 & 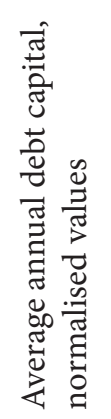 & 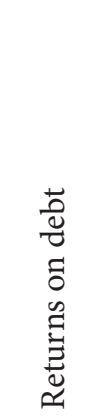 & 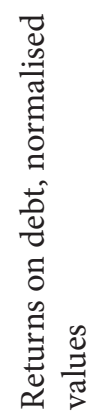 & 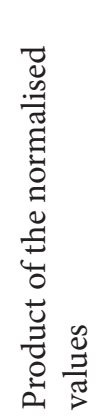 & 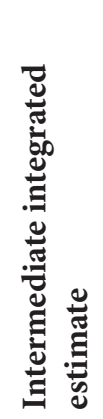 \\
\hline 2011 & 1.69 & 0.893 & 748909 & 0.895 & 0.004 & 0.037 & 0.029 & 0.309 \\
\hline 2012 & 1.44 & 0.761 & 734374 & 0.913 & 0.04 & 0.425 & 0.295 & 0.666 \\
\hline 2013 & 1.85 & 0.978 & 650277 & 1.031 & 0.09 & 0.883 & 0.891 & 0.962 \\
\hline 2014 & 2.33 & 1.234 & 589952 & 1.136 & 0.26 & 2.512 & 3.522 & 1.521 \\
\hline 2015 & 2.14 & 1.133 & 627999 & 1.067 & 0.12 & 1.143 & 1.382 & 1.114 \\
\hline $\bar{x}$ & 1.89 & $\mathrm{x}$ & 670302 & $\mathrm{x}$ & 0.10 & $\mathrm{x}$ & $\mathrm{x}$ & $\mathrm{x}$ \\
\hline
\end{tabular}




\section{Machinery shortage and deterioration}

\begin{tabular}{|c|c|c|c|c|c|c|c|c|}
\hline 节 & 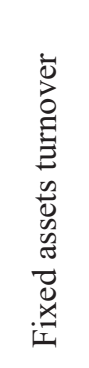 & 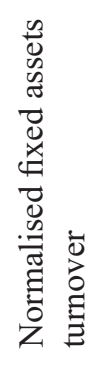 & 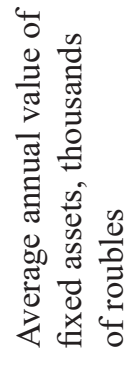 & 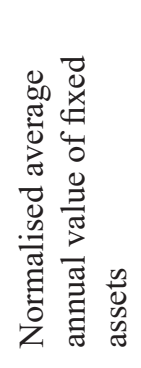 & 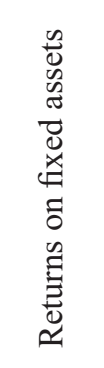 & 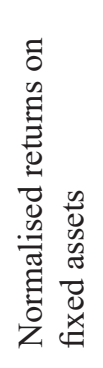 & 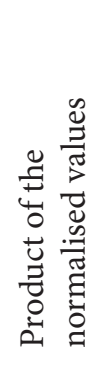 & 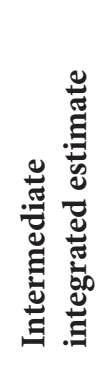 \\
\hline 2011 & 1.76 & 0.983 & 720372 & 1.032 & 0.42 & 0.045 & 0,046 & 0.358 \\
\hline 2012 & 1.58 & 0.881 & 671384 & 0.962 & 5.05 & 0.551 & 0.466 & 0.776 \\
\hline 2013 & 1.80 & 1.007 & 668642 & 0.98 & 8.65 & 0.942 & 0.909 & 0.969 \\
\hline 2014 & 1.94 & 1.087 & 708279 & 1.015 & 21.37 & 2.328 & 2.568 & 1.369 \\
\hline 2015 & 1.86 & 1.042 & 721756 & 1.034 & 10.40 & 1.134 & 1.222 & 1.069 \\
\hline$\overline{\mathrm{x}}$ & 1.82 & $\mathrm{x}$ & 698086 & $\mathrm{x}$ & 9.27 & $\mathrm{x}$ & $\mathrm{x}$ & $\mathrm{x}$ \\
\hline
\end{tabular}

The same procedure was performed using Option B. The findings for "High tax rate" and "High price of materials, components and articles" are shown in Table 5. The intermediate integral estimates are similar to those obtained by Option 1. For example, the factor of "High tax rate" has the reference year of 2011, "High price of materials, components and articles" - 2013; for "High interest for commercial credits" and "Machinery shortage and deterioration" the reference year is 2014 .

Table 5. Intermediate integrated estimates for High tax rate and High price of materials, components, and articles for the reporting period of 2011-2015, Option B

\section{High tax rate}

\begin{tabular}{|c|c|c|c|c|c|c|c|c|}
\hline 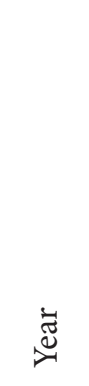 & 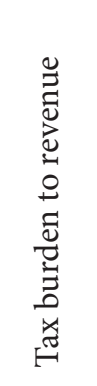 & 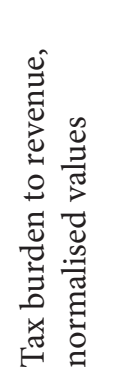 & 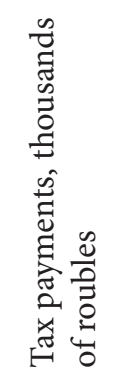 & 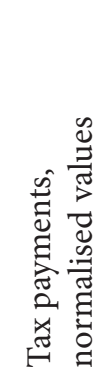 & 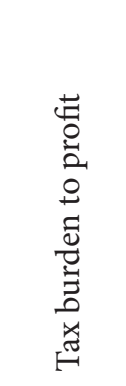 & 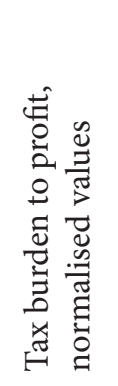 & 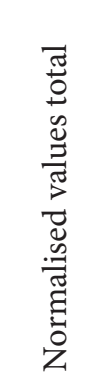 & 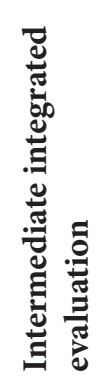 \\
\hline 2011 & 0.24 & 1 & 3029 & 0.591 & 104.16 & 0 & 2 & 0.667 \\
\hline 2012 & 1.48 & 0.441 & 15671 & 0.265 & 48.13 & 0.681 & 1.713 & 0.571 \\
\hline 2013 & 2.13 & 0.146 & 25722 & 0 & 42.91 & 0.749 & 1.156 & 0.385 \\
\hline 2014 & 2.46 & 0 & 33913 & 0.149 & 21.92 & 1 & 1 & 0.333 \\
\hline 2015 & 2.18 & 0.129 & 29281 & 0.591 & 39.09 & 0.791 & 1.070 & 0.357 \\
\hline $\bar{x}$ & 1.69 & $\mathrm{x}$ & 21523 & $\mathrm{x}$ & 51.24 & $\mathrm{x}$ & $\mathrm{x}$ & $\mathrm{x}$ \\
\hline
\end{tabular}




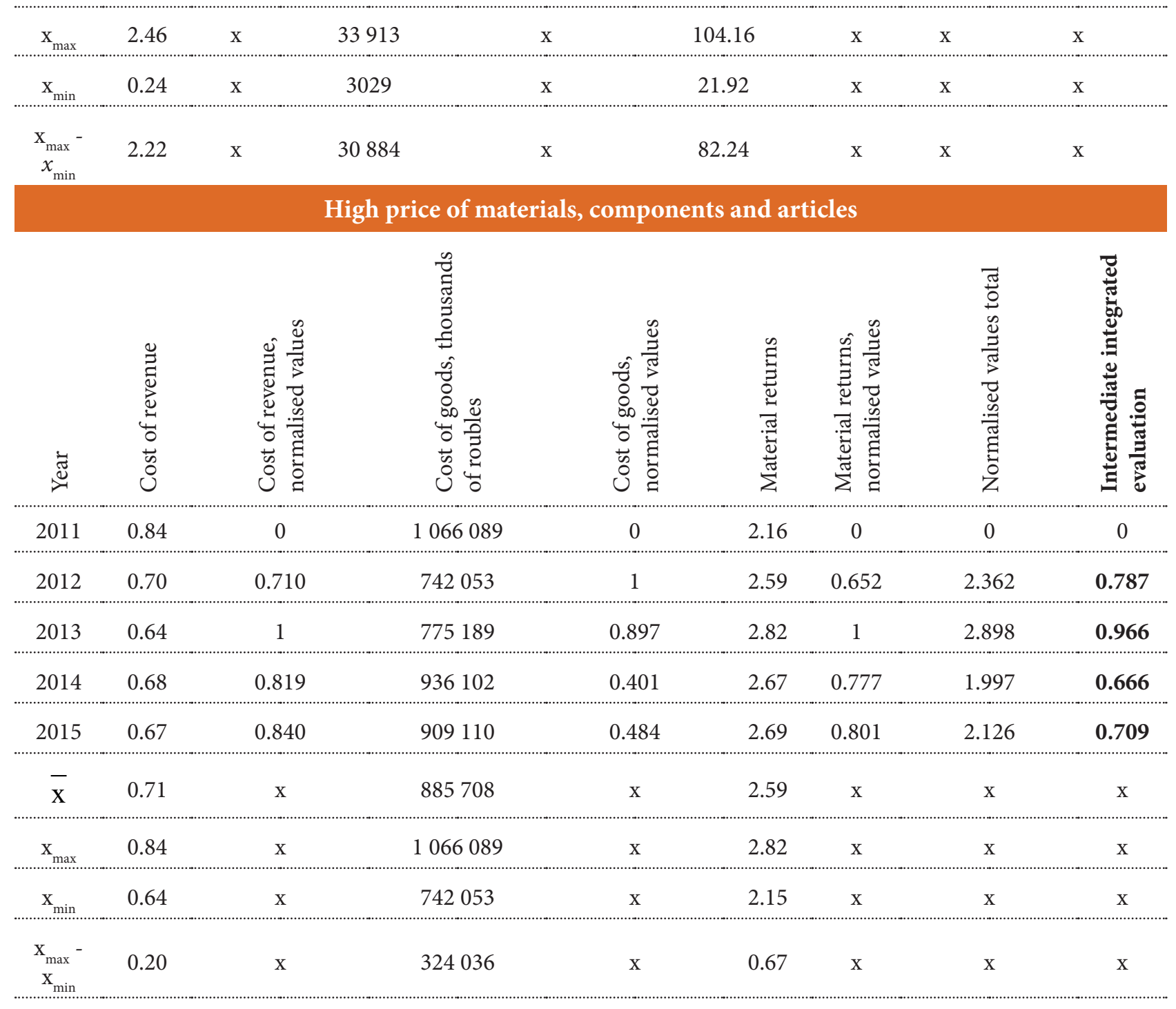

Table 6. Intermediate integrated estimates for high interest for commercial credits and machinery shortage and deterioration for the reporting period of 2011-2015, Option B

\section{High interest for commercial credits}

\begin{tabular}{|c|c|c|c|c|c|c|c|}
\hline 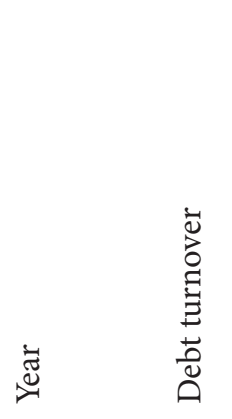 & 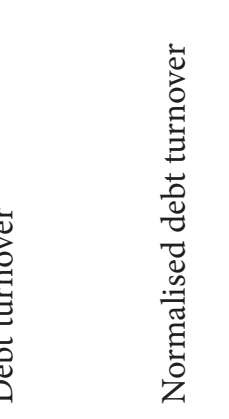 & 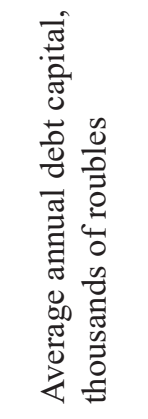 & 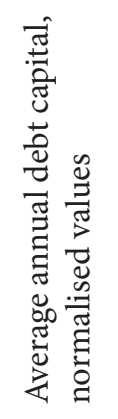 & 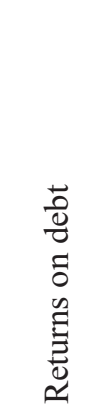 & 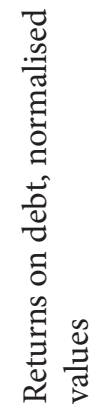 & 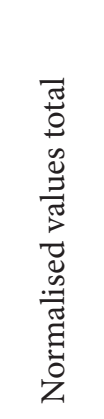 & 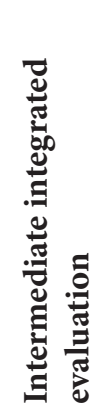 \\
\hline 1.69 & 0,279 & 748909 & 0 & 0.004 & 0 & 0.279 & 0.093 \\
\hline 1.44 & 0 & 734374 & 0.091 & 0.04 & 0.157 & 0.248 & 0.083 \\
\hline 1.85 & 0,459 & 650277 & 0.620 & 0.09 & 0.342 & 1.422 & 0.474 \\
\hline 2.33 & 33 & 589952 & 1 & 0.26 & 1 & 3 & 1 \\
\hline
\end{tabular}




\begin{tabular}{|c|c|c|c|c|c|c|c|c|}
\hline 2015 & 2.14 & 0,786 & 627999 & 0.761 & 0.12 & 0.447 & 1.993 & 0.664 \\
\hline$\overline{\mathrm{x}}$ & 1.89 & $\mathrm{x}$ & 670302 & $\mathrm{x}$ & 0.10 & $\mathrm{x}$ & $\mathrm{x}$ & $\mathrm{x}$ \\
\hline $\mathrm{x}_{\max }$ & 2.33 & $\mathrm{x}$ & 748909 & $\mathrm{x}$ & 0.104 & $\mathrm{x}$ & $\mathrm{x}$ & $\mathrm{x}$ \\
\hline $\mathrm{x}_{\min }$ & 1.44 & $\mathrm{x}$ & 589952 & $\mathrm{x}$ & 0.26 & $\mathrm{x}$ & $\mathrm{x}$ & $\mathrm{x}$ \\
\hline $\mathrm{x}_{\max }-\mathrm{x}_{\min }$ & 0.89 & $\mathrm{x}$ & 158957 & $\mathrm{x}$ & 0.004 & $\mathrm{x}$ & $\mathrm{x}$ & $\mathrm{x}$ \\
\hline \multicolumn{9}{|c|}{ Machinery shortage and deterioration } \\
\hline$\dot{\Xi}$ & 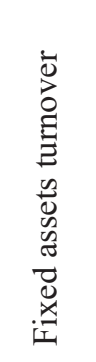 & 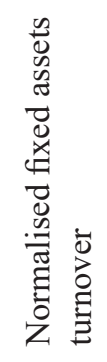 & 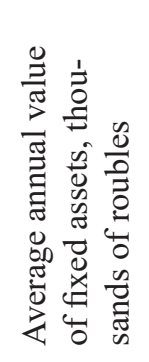 & 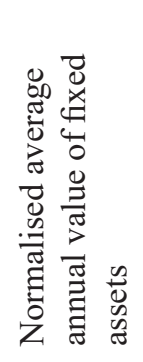 & 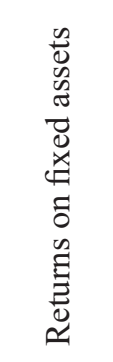 & 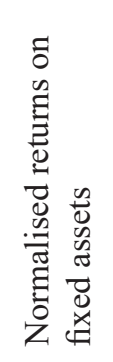 & 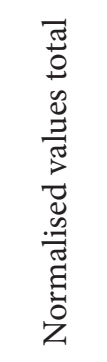 & 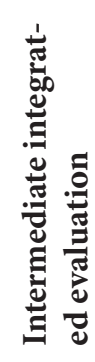 \\
\hline 2011 & 1.76 & 0.492 & 720372 & 0.974 & 0.42 & 0 & 1.466 & 0.489 \\
\hline 2012 & 1.58 & 0 & 671384 & 0.052 & 5.05 & 0.221 & 0.23 & 0.091 \\
\hline 2013 & 1.80 & 0.609 & 668642 & 0 & 8.65 & 0.393 & 1.002 & 0.334 \\
\hline 2014 & 1.94 & 1 & 708279 & 0.746 & 21.37 & 1 & 2.746 & 0.915 \\
\hline 2015 & 1.86 & 0.783 & 721756 & 1 & 10.40 & 0.477 & 2.259 & 0.753 \\
\hline$\overline{\mathrm{X}}$ & 1.82 & $\mathrm{x}$ & 698086 & $\mathrm{x}$ & 9.27 & $\mathrm{x}$ & $\mathrm{x}$ & $\mathrm{x}$ \\
\hline $\mathrm{x}_{\max }$ & 1.94 & $\mathrm{x}$ & 721756 & $\mathrm{x}$ & 21.37 & $\mathrm{x}$ & $\mathrm{x}$ & $\mathrm{x}$ \\
\hline $\mathrm{x}_{\min }$ & 1.58 & $\mathrm{x}$ & 668642 & $\mathrm{x}$ & 0.42 & $\mathrm{x}$ & $\mathrm{x}$ & $\mathrm{x}$ \\
\hline $\mathrm{x}_{\max }-\mathrm{x}_{\min }$ & 0.36 & $\mathrm{x}$ & 53114 & $\mathrm{x}$ & 20.95 & $\mathrm{x}$ & $\mathrm{x}$ & $\mathrm{x}$ \\
\hline
\end{tabular}

The next step is to make overall integrated assessments separately as per the procedures described in Option A and Option $B$ and then average them to produce a single overall estimate. The findings are summarised in Table 7.

Table 7. Derivation of Integrated estimates by Option A and Option B and total integrated evaluation for the reporting period of 2011-2015

\section{Option A}

\begin{tabular}{|c|c|c|c|c|c|c|}
\hline 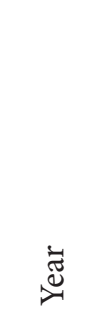 & 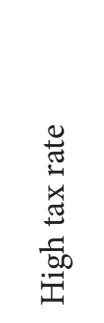 & 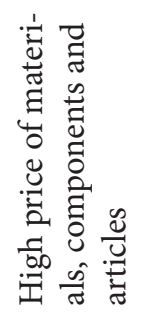 & 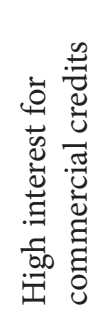 & 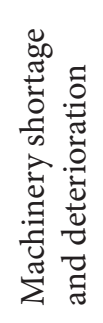 & 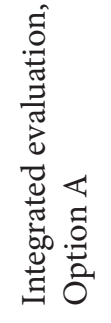 & $\frac{600}{\tilde{\Xi}}$ \\
\hline 2011 & 2.917 & 0.835 & 0.310 & 0.358 & 4.421 & 2 \\
\hline 2012 & 1.188 & 1.065 & 0.666 & 0.776 & 3.695 & 5 \\
\hline 2013 & 0.926 & 1.111 & 0.962 & 0.969 & 3.968 & 4 \\
\hline
\end{tabular}




\begin{tabular}{|c|c|c|c|c|c|c|}
\hline 2014 & 1.008 & 1.006 & 1.521 & 1.369 & 4.905 & 1 \\
\hline 2015 & 0.910 & 1.020 & 1.114 & 1.069 & 4.113 & 3 \\
\hline
\end{tabular}

\begin{tabular}{|c|c|c|c|c|c|c|}
\hline 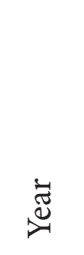 & 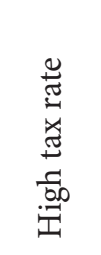 & 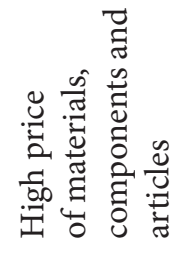 & 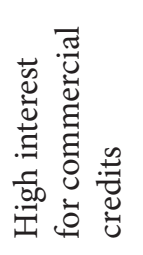 & 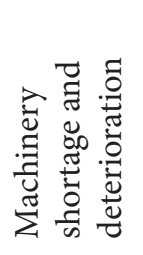 & 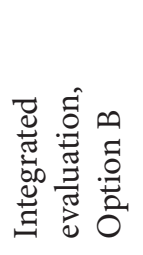 & 茴 \\
\hline 2011 & 0.667 & 0.000 & 0.093 & 0.489 & 1.249 & 5 \\
\hline 2012 & 0.571 & 0.787 & 0.083 & 0.091 & 1.532 & 4 \\
\hline 2013 & 0.386 & 0.966 & 0.474 & 0.334 & 2.159 & 3 \\
\hline 2014 & 0.333 & 0.666 & 1.000 & 0.915 & 2.915 & 1 \\
\hline 2015 & 0.357 & 0.709 & 0.664 & 0.753 & 2.483 & 2 \\
\hline \multicolumn{7}{|c|}{ Option $A$ and Option $B$ averaging } \\
\hline$\underset{\beth}{\circlearrowright}$ & 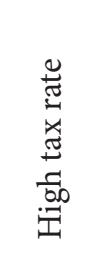 & 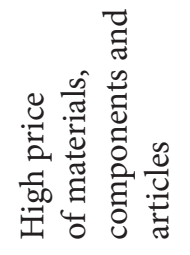 & 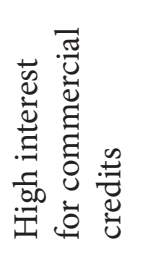 & 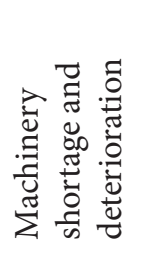 & 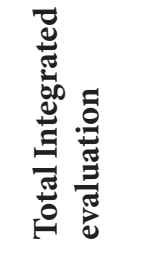 & 苞 \\
\hline 2011 & 1.792 & 0.418 & 0.202 & 0.424 & 0.709 & 4 \\
\hline 2012 & 0.880 & 0.926 & 0.374 & 0.433 & 0.653 & 5 \\
\hline 2013 & 0.656 & 1.038 & 0.718 & 0.651 & 0.766 & 3 \\
\hline 2014 & 0.671 & 0.836 & 1.261 & 1.142 & 0.977 & 1 \\
\hline 2015 & 0.633 & 0.865 & 0.889 & 0.911 & 0.824 & 2 \\
\hline
\end{tabular}

It is feasible to rank the integral estimates of Option A and Option B by reporting periods. Rank one is assessed as a target (reporting) magnitude. For the Joint Venture under consideration, the target periods obtained by Option A and Option B fall in the same period of 2014.

To obtain overall integral estimate, we need to average out Option A and Option B estimates (see Table 7). Similarly, rank the overall integral estimates by periods. Then, choose the best period for every selected organisation and compare the normalised values of Options A and B for every factor. The results are in Table 8 .

The calculations show that for the construction companies under consideration, the fundamental indicators include tax burden to profit, cost to sales revenue, returns on debt, fixed assets turnover and economy indicators for each factor. These metrics are capable of providing sufficient feedback about the performance of the construction companies in the sample throughout the reporting period in terms of their effectiveness, efficiency and economy. Besides, the indicators are intended to reveal the accountancy, managerial and taxation items that call for detailed auditing procedures to be implemented in order to evaluate the reliability of the reporting efforts and their compliance with the current legislation. Table 9 shows a relevant indicator framework for performance audit procedures. 
Table 8. Framework of relevant efficiency and effectiveness indicators

\begin{tabular}{|c|c|c|}
\hline \multicolumn{3}{|c|}{ High tax rate } \\
\hline Organisation & Tax burden to revenue & Tax burden to profit \\
\hline 1 & 2 & 3 \\
\hline № 1 & - & + \\
\hline № 6 & + & - \\
\hline № 9 & - & + \\
\hline № 10 & - & + \\
\hline № 12 & + & + \\
\hline № 14 & - & + \\
\hline Total & 2 & 5 \\
\hline \multicolumn{3}{|c|}{ High costs of raw materials, compounds, articles } \\
\hline Organisation & Cost to sales revenue & Material returns \\
\hline № 1 & + & + \\
\hline № 6 & + & - \\
\hline № 9 & + & - \\
\hline № 10 & + & - \\
\hline № 12 & + & - \\
\hline № 14 & + & - \\
\hline Total & 6 & 1 \\
\hline
\end{tabular}

High interest for commercial credits

Organisation

№ 1

№ 6

№ 9

№ 10

№ 12

№ 14

Total
Borrowed funds turnover

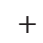

$+$

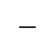

$-$

$+$

$+$

4
Returns on debt

$+$

$+$

$+$

$+$

$+$

$+$

6

Machinery shortage and deterioration

Organisation

№ 1

№ 6
Fixed assets turnover
Returns on fixed assets

$+$

$-$ 


\begin{tabular}{|c|c|c|}
\hline № 9 & + & - \\
\hline № 10 & + & - \\
\hline № 12 & - & + \\
\hline № 14 & + & + \\
\hline Total & 5 & 3 \\
\hline
\end{tabular}

Table 9. Performance audit criteria framework for construction organisations

\begin{tabular}{lcc} 
& Efficiency & \\
Cost to sales revenue & & Fixed assets turnover \\
& Effectiveness & Returns on debt \\
Tax burden (to profit) & Economy & \\
\hline
\end{tabular}

$\begin{array}{cccc}\begin{array}{c}\text { Elasticity of taxes } \\ \text { to revenue }\end{array} & \begin{array}{c}\text { Elasticity of cost of goods } \\ \text { to revenue }\end{array} & \begin{array}{c}\text { Elasticity of debt capital } \\ \text { to revenue }\end{array} & \begin{array}{c}\text { Elasticity of fixed assets } \\ \text { to revenue }\end{array}\end{array}$

In view of this, the most relevant efficiency criteria for construction companies are seen to be fixed assets turnover and cost to sales revenue. Therefore, we can suggest that the most essential criteria among the construction industry constraints are the condition of property, plant and equipment and production costs structure. Thus from the perspective of efficiency assessment, we should emphasise the audit procedures that allow for a detailed analysis of prime costs, depreciation, asset acquisitions, and disposals. With regard to effectiveness, the values that deserve thorough analysis are debt financing, tax burden and its impact on performance.

Therefore, the most salient feature of our approach to the proposed performance audit criteria system is that it reveals industry-specific controlled parameters and baseline information available for auditing procedures to be conducted in construction organisations. Having identified significant performance audit indicators, we can now distinguish the controlled parameters that are presented in Table 10.

Table 10. Performance audit criteria framework developed for construction organisations with monitoring parameters

\begin{tabular}{|c|c|c|}
\hline Criteria category & Criteria & Controlled parameters \\
\hline 1 & 2 & 3 \\
\hline \multirow{4}{*}{ Efficiency } & \multirow{2}{*}{ Cost to revenue } & Cost of goods \\
\hline & & Revenue \\
\hline & \multirow{2}{*}{ Fixed assets turnover } & Revenue \\
\hline & & Fixed assets average annual \\
\hline \multirow{2}{*}{ Effectiveness } & \multirow{2}{*}{ Tax burden (to profit) } & Tax payment \\
\hline & & Net profit (loss) \\
\hline \multirow{2}{*}{ Effectiveness } & \multirow{2}{*}{ Returns on debt } & Net profit (loss) \\
\hline & & Debt capital annual average \\
\hline
\end{tabular}

Debt capital annual average 


\begin{tabular}{|c|c|c|}
\hline Criteria category & Criteria & Controlled parameters \\
\hline \multirow{8}{*}{ Economy } & \multirow{2}{*}{ Elasticity of taxes to revenue } & Tax payment \\
\hline & & Revenue \\
\hline & \multirow{2}{*}{ Elasticity of cost of goods to revenue } & Cost of goods \\
\hline & & Revenue \\
\hline & \multirow{2}{*}{ Elasticity of debt capital to revenue } & Debt capital \\
\hline & & Revenue \\
\hline & \multirow{2}{*}{ Elasticity of fixed assets to revenue } & Fixed assets \\
\hline & & Revenue \\
\hline
\end{tabular}

To provide further performance estimation, consider the controlled parameters summarised in Table 11.

Table 11. Historical analysis of controlled parameters of the Joint Stock Company for the reporting period of 2015-2016

\begin{tabular}{|c|c|c|c|c|c|}
\hline \multirow{2}{*}{$\begin{array}{l}\text { Controlled parameters, } \\
\text { thousand roubles }\end{array}$} & \multicolumn{2}{|c|}{ Year } & \multirow{2}{*}{$\begin{array}{l}\text { Growth } \\
\text { rate, } \%\end{array}$} & \multirow{2}{*}{$\begin{array}{c}\text { Increment, } \\
\%\end{array}$} & \multirow{2}{*}{$\begin{array}{l}\text { Absolute devi- } \\
\text { ation, thou- } \\
\text { sand roubles }\end{array}$} \\
\hline & 2015 & 2016 & & & \\
\hline 1 & 2 & 3 & 4 & 5 & 6 \\
\hline Revenue & 1359373 & 1181227 & 86.8 & -13.2 & -178146 \\
\hline Net profit & 35118 & 128276 & 365.2 & 265.2 & 93158 \\
\hline Tax payment & 38269 & 35701 & 93.2 & -6.8 & -2568 \\
\hline Debt capital annual average & 459443 & 430395 & 93.6 & -6.4 & -29048 \\
\hline Fixed assets average annual & 703439 & 693165 & 98.5 & -1.5 & -10274 \\
\hline Price of goods & 894988 & 696656 & 77.8 & -22.2 & -198332 \\
\hline Fixed assets & 687027 & 699303 & 101.7 & 1.7 & 12276 \\
\hline Debt capital & 402711 & 458079 & 113.7 & 13.7 & 55368 \\
\hline
\end{tabular}

To evaluate efficiency, calculate the profitability ratios presented in Table 12. 
Table 12. Joint Stock Company profitability ratios for the reporting period of 2015-2016

\begin{tabular}{|c|c|c|c|c|}
\hline \multirow{2}{*}{$\begin{array}{l}\text { Company performance } \\
\text { indicators }\end{array}$} & \multirow{2}{*}{ Formula } & \multicolumn{2}{|c|}{ Year } & \multirow{2}{*}{ Change $(+,-)$} \\
\hline & & 2015 & 2016 & \\
\hline 1 & 2 & 3 & 4 & 5 \\
\hline Profit margin from core operations & $\begin{array}{l}\text { Net income / } \\
\text { (production cost + overheads } \\
+ \text { selling and marketing expenses) }\end{array}$ & 0,163 & 0,204 & 0,041 \\
\hline Returns on assets & Net profit / Average total assets & 0.025 & 0.089 & 0.064 \\
\hline Returns on equity & Net profit / Average equity capital & 0.045 & 0.148 & 0.103 \\
\hline Returns on sales & Net income / Revenue & 0.140 & 0.169 & 0.029 \\
\hline Returns on fixed assets & Net profit / Average fixed assets & 0.051 & 0.183 & 0.132 \\
\hline
\end{tabular}

As shown in the table, the efficiency indicators demonstrate a positive trend. Nevertheless, to understand what actually created this trend, factor analysis has been conducted for every efficiency indicator.

A factor analysis of operations was conducted by the method of chain substitute. Its results provide the evidence sufficient to assess the impact of monitoring parameters on company performance. Table 13 summarises the results obtained.

Table 13. The impact of controlled parameters on company performance obtained through factor analysis for the reporting period of 2011-2015: Summary Table

\begin{tabular}{|c|c|c|c|c|}
\hline $\begin{array}{l}\text { Profitability } \\
\text { ratios }\end{array}$ & $\begin{array}{l}\text { Controlled } \\
\text { parameters }\end{array}$ & $\begin{array}{l}\text { Absolute } \\
\text { variation, } \\
\text { thousand } \\
\text { rubbles. }\end{array}$ & $\begin{array}{l}\text { Positive / } \\
\text { Negative } \\
\text { impact }\end{array}$ & $\begin{array}{c}\text { Materiality } \\
\text { assessment, \% }\end{array}$ \\
\hline Profit margin from core operations & Price of goods & -198332 & + & 28. 469 \\
\hline Returns on assets & Net profit (loss) & 93158 & + & 72.623 \\
\hline Returns on equity & Net profit (loss) & 93158 & + & 72.623 \\
\hline Returns on sales & Revenue & -178146 & + & 15.081 \\
\hline \multirow{2}{*}{ Returns on fixed assets } & Net profit (loss) & 93158 & + & 72.623 \\
\hline & Fixed assets & 12276 & - & 1.755 \\
\hline
\end{tabular}

As is seen from the table, the assessment of deviation materiality on the controlled parameters emphasises a number of indicators that are to be found in financial statements. For the construction organisation under examination, those indicators are as follows: price of construction work, net profit (loss) and revenue. Therefore, to interpret these values, the auditor has to reach out to additional information that affects the behaviour of the controlled parameters. Such information includes accounting policies on the price of goods formation (assessment methods of inventory disposal, capital assets depreciation, reserve accumulation policy, etc.). Thus, when interpreting performance audit evidence, account- ing policy is considered with reference to the indicators of effectiveness, efficiency and economy (by 'accounting policy' we mean the policies that are not restricted to merely accounting objectives but also concern the issues of corporate profit taxation).

Another indicator to be specified is revenue. When examining a company's revenue, the auditor should understand its pattern and see how it fits the declared activities. He also should examine how well the audited entity maintains separate activity-based records of income and expenses. The revenue structure for the Joint Stock Company under consideration is provided in the notes to the Company's accounting statement (See Table 14). 
Table 14. Revenue of the Joint Venture Company by type of activity for the reporting period of 2015-2016

\begin{tabular}{|c|c|c|c|}
\hline $\begin{array}{l}\text { № } \\
\text { п/ } \\
\end{array}$ & Indicator & $\begin{array}{l}\text { Revenue VAT exclusive, } \\
2016 \text {, roubles }\end{array}$ & $\begin{array}{l}\text { Revenue VAT exclusive, } \\
2015 \text {, roubles }\end{array}$ \\
\hline 1 & Selling own production (Foam concrete) & 1064759788 & 1165710643 \\
\hline 2 & $\begin{array}{l}\text { Construction and assembling operations, } \\
\text { contractor's activities }\end{array}$ & 3192367 & 50449400 \\
\hline 3 & Rental services & 30182217 & 40621766 \\
\hline 4 & $\begin{array}{l}\text { Providing services, work execution (including } \\
\text { delivery) }\end{array}$ & 56139530 & 65885422 \\
\hline 5 & Sales of real estates and land property & 2312369 & 11500000 \\
\hline \multirow[t]{2}{*}{6} & Sales of purchased goods & 24640676 & 25206049 \\
\hline & TOTAL & 1181226947 & 1359373280 \\
\hline
\end{tabular}

Thus, the method developed within the study has been tested using the reporting of construction companies operating in the Novosibirsk region. To yield and analyze performance audit criteria we initially selected sixteen construction companies throughout the Novosibirsk region. However, for the criteria to work well and adequately reflect the performance with reference to effectiveness, efficiency and economy, we had to reduce the sampling to six organisations. To obtain relevant indicators of effectiveness and efficiency for the six organisations, we identified their best period and compared the normalised values, estimated by Option A and Option B for each factor.

\section{Conclusion and Further research}

This paper sought to draw up a set of criteria and analytical procedures for performance auditing in construction companies. It identifies some significant results and opens opportunities for future research.

The demonstrated results have confirmed our hypothesis that performance audit tools can provide a comprehensive solution to the problem of information openness and fairness in relation to the assessment of construction organisation performance.

First, we used valid statistical methods to determine certain significant indicators describing performance audit criteria. These indicators have been validated by compelling evidence elicited from sixteen construction organisations, over a period of five years.

Second, to establish significant indicators regarding efficiency, effectiveness and economy, auditing procedures were identified. This range of performance audit procedures was selected due to its having the capacity to provide comprehensive analysis of relevant information to measure key performance indicators.

Third, all the profitability indicators were subjected to factoral analysis that enabled us to assess the impact of certain controlled parameters vis-a-vis the performance results. The materiality of deviation for controlled parameters was estimated, and this allowed for the emphasising of some of the indicators gleaned from financial statements. Thus, it was identified as the information that is particularly important, meaning a strong emphasis should be put on this information's accuracy and fairness.

Fourth and lastly, we implemented performance audit procedures in order to systematise accounting policy information, which has implications for the applied parameters. This was to enable the identification of the most pertinent items to be disclosed through reporting.

The provided study of accounting policies of a Joint Stock Company has shown that the organisation utilises a weighted average cost method to compute the depreciation of goods sold, final products, financial assets and inventory. This method works well when purchasing prices tend to fluctuate sharply. In this case, prime costs averaging is shown to help avoid both unpredictable losses and unexpected revenue rates.

Therefore, the method demonstrated in this study provides guidelines to ensure accounting and analytical support of performance audit in construction organisations. This enables the creation of a system of performance audit criteria, the determination of their reference values, and the establishment of a set of controlled parameters. Being equipped with the controlled parameters, we can streamline accounting information, (including tax information and the information available through accounting statements) in terms of its materiality for stakeholders. Through this framework, stakeholders may evaluate a company's performance against the criteria of efficiency, effectiveness and economy. We should note that performance audit findings are especially important for internal users to validate their managerial decisions, as well as for external users making investment decisions.

It is necessary to expand and strengthen the results provided herein through further research. Firstly, we could see that statistical methods can fully validate the framework and reference values for performance audit criteria. 
Nevertheless, to accomplish this task, we need to obtain information applicable to longer periods of at least several years. This will allow for the setting of benchmarks not against budget and forecast values, but using the information on the dynamics of effectiveness and efficiency of resources utilisation. Additionally, there is still a gap in the understanding of performance criteria with regard to many construction companies that continue to lose business. Secondly, using integrated estimates to rank relevant indicators of efficiency, effectiveness and economy enabled us to determine and specify controlled parameters. Controlled parameters create a reliable framework to present accounting and tax information in a systematic manner and assess the quality and reliability of its disclosure. This is a contribution to auditor sampling methodology and needs further development in the context of auditor review of material information disclosures. Thirdly, the research points out the need to supply stakeholders with information on effectiveness, efficiency and economy to provide them with comprehensive understanding of performance prospects in a broader socio-economic context. This means that construction companies need to disclose non-financial reporting, or expand their financial reporting with quality parameters. This creates an opportunity for further research on how the amount and quality of information disclosed in companies' reports impact business activities and the reputation of a construction company.

\section{References}

1. Alkebsi M., Azman Aziz K. Information technology usage, top management support and internal audit effectiveness. Asian Journal of Accounting \& Governance. Special Issue. 2017;8:123-132. DOI: 10.17576/AJAG-2017-08SI-11

2. Arnold $\mathrm{V}$. The changing technological environment and the future of behavioural research in accounting. Accounting \& Finance. 2018;58(2):315-339. DOI: 10.1111/acfi.12218

3. Mullis C.E., Hatfield R.C. The effects of multitasking on auditors' judgment quality. Contemporary Accounting Research. 2018;35(1):314-333. DOI: 10.1111/1911-3846.12392

4. Masiulevičius A., Lakis V. Differentiation of performance materiality in audit based on business needs. Entrepreneurship and Sustainability Issues. 2018;6(1):115-124. DOI: 10.9770/jesi.2018.6.1(9)

5. Nazir M.S., Afza T. Does managerial behavior of managing earnings mitigate the relationship between corporate governance and firm value? Evidence from an emerging market. Future Business Journal. 2018;4(1):139-156. DOI: 10.1016/j.fbj.2018.03.001

6. Palaniappan G. Determinants of corporate financial performance relating to board characteristics of corporate governance in Indian manufacturing industry: An empirical study. European Journal of Management and Business Economics. 2017;26(1):6785. DOI: 10.1108/EJMBE-07-2017-005
7. Alnabsha A, Abdou H.A., Ntim C.G., Elamer A.A. Corporate boards, ownership structures and corporate disclosures: Evidence from a developing country. Journal of Applied Accounting Research. 2018;19(1):20-41. DOI: 10.1108/JAAR-01-2016-0001

8. Construction. RF Federal State Statistics Service. 2015. URL: http://www.gks.ru/wps/wcm/connect/ rosstat_main/rosstat/ru/statistics/enterprise/ building/\# (accessed on 11.01.2017). (in Russ.).

9. Factors restricting the production activities of construction organizations. RF Federal State Statistics Service. 2017. URL: http://www.gks.ru/ dbscripts/ cbsd/dbinet.cgi?pl=9000245.htm (accessed on 03.04.2017). (in Russ.).

10. Appendix No. 3 to the Order of the Federal Tax Service of Russia dated 05.30.2007 No. MM-3-06/333 @ (updated taking into account data for 2016). Federal Tax Service of Russia. 2016. URL: https:// www.nalog.ru/rn77/taxation/reference_work/ conception_vnp/ (accessed on 20.12.2017). (in Russ.).

11. Construction in Russia. 2016: Statistical collection. Moscow: Rosstat; 2016. 111 p. URL: http://www.gks. ru/free_doc/doc_2016/stroit_2016.pdf (in Russ.).

12. Sklyarov I. Shortage and wearout of equipment is nothing for builders. Ekonomika i zhizn'. 2012;(18). URL: http://www.egonline.ru/article/174272/ (accessed on 01.02.2015). (in Russ.).

13. Methodology for conducting an audit of the effectiveness of using public funds. Adopted by a decision of the Board of the Accounts Chamber of the Russian Federation of April 23, 2004, protocol No. 13 (383). URL: http://base.garant.ru/12160250/ (accessed on 01.02.2015). (in Russ.).

14. Appendix 2 to the resolution of the control and accounting body of the municipality - the Audit Chamber of the city of Nizhnevartovsk dated 06.06.2013 No. 6. URL: http://www.n-vartovsk. $\mathrm{ru} /$ authorities/town_sp /sp_deyatelnost/mm $\mathrm{sfk} / 165448 . h t m l$ (accessed on 03.11. 2015). (in Russ.).

15. Human Development Report 2016: Human development for everyone. New York: United Nations Development Programme; 2016. 286 p. URL: http:// hdr.undp.org/sites/default/files/2016_human_ development_report.pdf (accessed on 11.01.2017).

16. Senatorova E. Non-financial reporting: International context, Russian practice. Korporativnye finansy $=$ Journal of Corporate Finance Research. 2018;12(3):8192. DOI: $10.17323 /$ j.jcfr.2073-0438.12.3.2018.80-92 (in Russ.).

17. Butaeva E. Organizational governance system of urban planning in the Russian Federation. Pravovye voprosy stroitelstva. 2012;(2):3-7. (in Russ.).

18. Chudilin G., Geniatulina K. Variability of multidimensional estimates of the economic development of municipalities. Voprosy statistiki. 2005;(12):38-43. (in Russ.). 